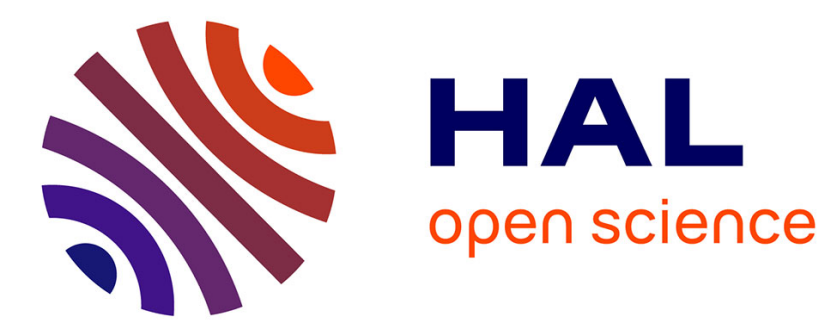

\title{
Gene network analysis leads to functional validation of pathways linked to cancer cell growth and survival.
}

Emmanuelle Berger, Nathalie Vega, Hubert Vidal, Alain Geloen

\section{To cite this version:}

Emmanuelle Berger, Nathalie Vega, Hubert Vidal, Alain Geloen. Gene network analysis leads to functional validation of pathways linked to cancer cell growth and survival.. Biotechnology Journal, 2012, 7 (11), pp.1395-404. 10.1002/biot.201200188 . inserm-00813081

\section{HAL Id: inserm-00813081 https://www.hal.inserm.fr/inserm-00813081}

Submitted on 15 Apr 2013

HAL is a multi-disciplinary open access archive for the deposit and dissemination of scientific research documents, whether they are published or not. The documents may come from teaching and research institutions in France or abroad, or from public or private research centers.
L'archive ouverte pluridisciplinaire HAL, est destinée au dépôt et à la diffusion de documents scientifiques de niveau recherche, publiés ou non, émanant des établissements d'enseignement et de recherche français ou étrangers, des laboratoires publics ou privés. 


\section{Supporting informations}

Table S1: Human gene sets retrieved from published experiments and used to determine gene sets detected in HepG2 cells (Full), liver (set 1) or deregulated in hepatocellular carcinoma HCC (set2).

\begin{tabular}{|c|c|c|c|}
\hline & Number of genes & PMID & References \\
\hline Full & 20839 & $\begin{array}{l}1345164 \\
11466695 \\
15013840 \\
17967932 \\
20571111 \\
127558421\end{array}$ & $\begin{array}{l}\text { Okubo et al , } 1992 \\
\text { Tackel Hornes et al , } 2001 \\
\text { Butura et al , } 2004 \\
\text { Liguori et al , } 2008 \\
\text { Berger et al , } 2010 \\
\text { De Gottardi et al , } 2007\end{array}$ \\
\hline Liver (set 1) & 4918 & $\begin{array}{r}1577423 \\
1676090 \\
10694486 \\
11580139\end{array}$ & $\begin{array}{l}\text { Shyamsundare et al , } 2005 \\
\text { Das et al , } 2006 \\
\text { Yamashita et al , } 2000 \\
\text { Yano et al , } 2001\end{array}$ \\
\hline HCC (set 2) & 806 & $\begin{array}{r}19171046 \\
18171335 \\
181711335\end{array}$ & $\begin{array}{l}\text { Okabe et al , } 2001 \\
\text { Wong et al , } 2008 \\
\text { Zender et al , } 2010\end{array}$ \\
\hline
\end{tabular}


Table S2: Drugs used in experiments

\begin{tabular}{|c|c|c|c|c|c|}
\hline Drug & Activity & $\begin{array}{c}\text { Highest } \\
\text { Concentration } \\
\text { tested }\end{array}$ & Reference (PMID) & Vehicle & Purchased by \\
\hline 2,5 DDA & Adenylate cyclase inhibitor & $100 \mu \mathrm{M}$ & 21444924 & Dimethylsulfoxide (DMSO) & SIGMA ALDRICH, France \\
\hline A6355 & P42/P44 inhibitor & $90 \mu \mathrm{M}$ & & DMSO & SIGMA ALDRICH, France \\
\hline Butein & Janus kinase (JAK1) inhibitor & $20 \mu \mathrm{M}$ & 9571170 (HepG2) & DMSO & SIGMA ALDRICH, France \\
\hline Compound C & AMPc activated kinase (AMPK) inhibitor & $40 \mu \mathrm{M}$ & 22674626 & DMSO & SIGMA ALDRICH, France \\
\hline GW7647 & $\begin{array}{l}\text { Peroxisome-proliferator activated receptor } \\
\text { alpha (PPARA) activator }\end{array}$ & $10 \mu \mathrm{M}$ & 188520 & DMSO & SIGMA ALDRICH, France \\
\hline KT5720 & $\begin{array}{l}\text { Protein kinase AMPc dependant (PKA) } \\
\text { inhibitor }\end{array}$ & $30 \mu \mathrm{M}$ & & Methanol (MetOH) & SIGMA ALDRICH, France \\
\hline LY294002 & PI3Kinase inhibitor & $250 \mu \mathrm{M}$ & 22025081 (HepG2) & DMSO & $\begin{array}{l}\text { CELL SIGNALING, Ozyme, St } \\
\text { Quentin-en-Yvelines, France }\end{array}$ \\
\hline P3115 & $\begin{array}{l}\text { Protein kinase Calcium dependant (PKC) } \\
\text { inhibitor }\end{array}$ & $50 \mu \mathrm{M}$ & 8420972 & $\mathrm{H} 2 \mathrm{O}$ & SIGMA ALDRICH, France \\
\hline Pertussis Toxin & $\mathrm{G}$ protein subunit $\mathrm{Gi} / \mathrm{G} 0$ inhibitor & $1 \mu \mathrm{g} / \mathrm{ml}$ & & $\mathrm{H} 2 \mathrm{O}$ & SIGMA ALDRICH, France \\
\hline Rapamycin & TOR/P70S6Kinase inhibitor & $50 \mathrm{nM}$ & $15870276 ; 21830446$ & $\mathrm{H} 2 \mathrm{O}$ & $\begin{array}{l}\text { CELL SIGNALING, Ozyme, St } \\
\text { Quentin-en-Yvelines, France }\end{array}$ \\
\hline RU 486 & PPARA inhibitor & $5 \mu \mathrm{M}$ & & $\mathrm{H} 2 \mathrm{O}$ & SIGMA ALDRICH, France \\
\hline SD169 & P38 MAP Kinase (P38MAPK) inhibitor & $300 \mu \mathrm{M}$ & 16603672 & DMSO & SIGMA ALDRICH, France \\
\hline SP600125 & Jun-NH2 kinase (JNK) inhibitor & $100 \mu \mathrm{M}$ & 14766793 (HepG2) & DMSO & SIGMA ALDRICH, France \\
\hline Tyrphostin 490 & Janus kinase 2 (JAK2) inhibitor & $50 \mu \mathrm{M}$ & 18448488 & Ethanol $(\mathrm{EtOH})$ & SIGMA ALDRICH, France \\
\hline U0126 & MEK1/2 MAPK inhibitor & $100 \mu \mathrm{M}$ & 18448488 & DMSO & $\begin{array}{l}\text { CELL SIGNALING, Ozyme, St } \\
\text { Quentin-en-Yvelines, France }\end{array}$ \\
\hline U73122 & $\begin{array}{l}\text { Phospholipase C (PLC and Phospholipase } \\
\text { A2 (PLA2) inhibitor }\end{array}$ & $5 \mu \mathrm{M}$ & 18629476 & $\mathrm{EtOH}$ & SIGMA ALDRICH, France \\
\hline Wedelolactone & $\begin{array}{l}\text { Nuclear factor kappa B, p65 subunit } \\
\text { (NFKBp65) inhibitor }\end{array}$ & $10 \mu \mathrm{M}$ & 17942463 & DMSO & SIGMA ALDRICH, France \\
\hline ZM39923 & Janus kinase 3 (JAK3 inhibitor & $50 \mu \mathrm{M}$ & 10741557 & DMSO & SIGMA ALDRICH, France \\
\hline
\end{tabular}


Table S3: References of human gene sets retrieved from published experiments and used to determine pathway representativity in either human genes detected in HepG2 cells (Full), liver or deregulated in hepatocellular carcinoma (HCC). Gene number ( $n$ ) in data sets represent the number of genes modulated by at least one pathway in either Full, liver or HCC sets. Gene sets modulated by external factors (Stimulus) and intracellular pathways were retrieved from experiments performed in human cells (PubMed Identifiers, PMID) and sets obtained on HepG2 cells are reported separately. Only significant Z-test scores are reported (confidence level > 90).

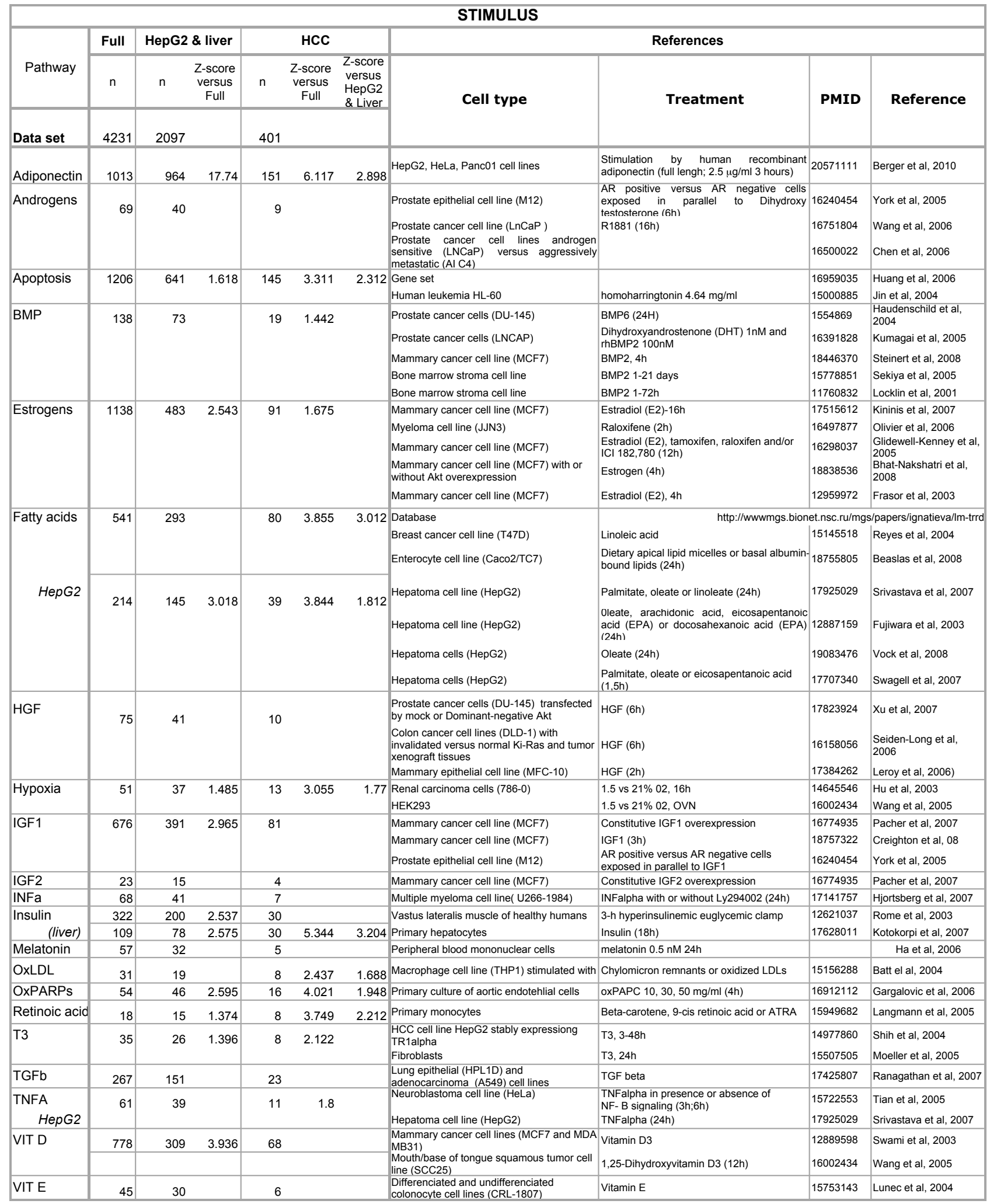




\begin{tabular}{|c|c|c|c|c|c|c|c|c|c|c|}
\hline \multicolumn{11}{|c|}{ Intracellular pathways } \\
\hline \multirow[b]{2}{*}{ Pathway } & \multirow{2}{*}{$\begin{array}{c}\text { Full } \\
\mathrm{n}\end{array}$} & \multicolumn{2}{|c|}{ HepG2 \& liver } & \multicolumn{3}{|c|}{$\mathrm{HCC}$} & \multicolumn{4}{|c|}{ References } \\
\hline & & 2529 & $\begin{array}{c}\text { Z-score } \\
\text { versus } \\
\text { Full }\end{array}$ & 453 & $\begin{array}{l}Z \text {-score } \\
\text { versus } \\
\text { Full }\end{array}$ & $\begin{array}{l}\text { Z-score } \\
\text { versus } \\
\text { HepG2 } \\
\text { \& Liver }\end{array}$ & Cell type & Treatment & PMID & Reference \\
\hline Akt & 1009 & 418 & & 79 & & & $\begin{array}{l}\text { Prostate cancer cells (DU-145) } \\
\text { Umbilical vein endotheliual cells (HUVECs) } \\
\text { Mammary cancer cell line (MCF7) } \\
\text { Retinoic pigment epithelial cells (RPE) } \\
\text { expressing constitutively } \\
\text { active Akt fused to the hormone } \\
\text { binding domain of the oestrogen receptor }\end{array}$ & $\begin{array}{l}\text { Transfection DN-Akt and stimulation by } \\
\text { HGF (6h) } \\
\text { Infected with adenoviral constitutively active } \\
\text { Akt (24h) } \\
\text { Constitutive Akt overexpression } \\
\text { 4-hydroxytamoxifen (4-OHT) }\end{array}$ & $\begin{array}{l}17823924 \\
15784720 \\
18838536 \\
16007182\end{array}$ & $\begin{array}{l}\text { Xu et al, } 2007 \\
\text { Kim et al, } 2005 \\
\text { Bhat-Nakshatri et al, } \\
2008 \\
\text { Portsmann et al, } 2005\end{array}$ \\
\hline $\begin{array}{l}\text { Akt } \\
\text { Translation }\end{array}$ & 92 & 84 & 4.831 & 11 & & & $\begin{array}{l}\text { Polysom microarray analysis of protsate can } \\
\text { stably transfected with a constitutively active }\end{array}$ & $\begin{array}{l}\text { ncer LAPC- } 4 \text { cell line } \\
\text { AKT and treated by rapamycin }\end{array}$ & 14576155 & Gera et al, 2004 \\
\hline $\mathrm{Gb} / \mathrm{g}$ & 22 & 14 & & 4 & & & $\begin{array}{l}\text { Knock out beta and gamma G protein } \\
\text { subunit }\end{array}$ & & 15983374 & Hwang et al, 2005 \\
\hline JNK & 74 & 49 & 1.969 & 18 & 4.184 & 2.473 & Epidermal keratinocytes & SP600125 (4h) & 16648634 & Gazel et al, 2006 \\
\hline Ki-RAS & 73 & 44 & 1.665 & 6 & & & 4 pancreatic cancer cell lines & Infection by adenoviral Ki-Ras antisens & 16446406 & Spence et al, 2006 \\
\hline LKB1 & 36 & 15 & & 4 & & & Lung adenocarinoma cells (A549) & LKB1 overexpression (6h) & 12649203 & Jimenez et al, 2003 \\
\hline Mek/Erk1/2 & 103 & 50 & & 9 & & & $\begin{array}{l}\text { Immortalized retinal pigment epithelial cells } \\
\text { (RPE) } \\
\text { Lung carcinoma cells (H157) }\end{array}$ & $\begin{array}{l}\text { Transient MKK1 or ERK2 overexpression } \\
\text { U0126 and/or plaxitel (6h) }\end{array}$ & $\begin{array}{l}16735500 \\
12941840\end{array}$ & $\begin{array}{l}\text { Schweppe et al, } 2006 \\
\text { Taxman et al, } 2003\end{array}$ \\
\hline $\begin{array}{l}\text { Methylation } \\
\text { (HepG2) }\end{array}$ & 3972 & 1719 & & 265 & 4.818 & 3.684 & $\begin{array}{l}\text { HCC cell line HepG2 } \\
\text { HCC cell line HepG2 }\end{array}$ & $\begin{array}{l}5-\mathrm{AzaC} \\
\text { 5-AzaC, TSA }\end{array}$ & $\begin{array}{l}16649225 \\
16854234\end{array}$ & $\begin{array}{l}\text { Arai et al, } 2006 \\
\text { Dannenberg et al, } 2006\end{array}$ \\
\hline MKK5/Erk5 & 26 & 18 & 1.556 & 5 & 1.675 & & $\begin{array}{l}\text { Immortalized retinal pigment epithelial cells } \\
\text { (RPE) }\end{array}$ & Transient MKK5 or ERK5 overexpression & 16735500 & Schweppe et al, 2006 \\
\hline mTOR & 540 & 269 & & 50 & & & $\begin{array}{l}\text { Hepatic cell line (HepaRG) } \\
\text { Jurkat T cells }\end{array}$ & $\begin{array}{l}\text { Constitutively active mTOR overexpression } \\
\text { Rapamycin ( } 3 \text { days) }\end{array}$ & $\begin{array}{l}17483347 \\
11943782\end{array}$ & $\begin{array}{l}\text { Parent et al, } 2007 \\
\text { Grolleau et al, } 2002\end{array}$ \\
\hline $\begin{array}{l}\text { mTOR } \\
\text { translation }\end{array}$ & 280 & 221 & 6.596 & 31 & 1.664 & & $\begin{array}{l}\text { Proteomic Profiling by } 2 \mathrm{D} \text {-electrophoresis of } \\
\text { Polysom microarray analysis of protsate can } \\
\text { line treated by rapamycin }\end{array}$ & $\begin{array}{l}\text { Rapamycin-treated Jurkat T Cells } \\
\text { ncer LAPC-4 and glioblastoma U87MG cell }\end{array}$ & 11943782 & $\begin{array}{l}\text { Grolleau et al, } 2002 \\
\text { Gera et al, } 2004\end{array}$ \\
\hline N-RAS & 400 & 281 & 6.028 & 79 & 7.548 & 3.531 & $\begin{array}{l}\text { Cancer cell lines (SHEP, A549, NCIH929, } \\
\text { U87 and LaNR) } \\
\text { Cord blood CD } 34+\text { cells }\end{array}$ & $\begin{array}{l}\text { Salirasib } \\
\text { Constitutive N-RAS expression }\end{array}$ & $\begin{array}{r}17409441 \\
17533045\end{array}$ & $\begin{array}{l}\text { Blum et al, } 2007 \\
\text { Shen et al, } 2007\end{array}$ \\
\hline P38MAPK & 91 & 71 & 3.526 & 25 & 5.69 & 2.854 & Follicular lymphoma cell line (OCILY-1) & SB203580 & 15169874 & Lin et al, 2004 \\
\hline Pi3K & 72 & 38 & & 6 & & & $\begin{array}{l}\text { Gioblastoma cell line (T98G) } \\
\text { Multiple myeloma cell line( U266-1984) }\end{array}$ & $\begin{array}{l}\text { LY294002 (3h) } \\
\text { Ly294002 (24h) }\end{array}$ & $\begin{array}{l}18226221 \\
17141757\end{array}$ & $\begin{array}{l}\text { Terragni et al, } 2008 \\
\text { Hjortsberg et al, } 2007\end{array}$ \\
\hline PKA & 89 & 39 & & 10 & 0.945 & & $\begin{array}{l}\text { Prostate cancer cell line (LnCaP ) } \\
\text { Endometrial stromal cells }\end{array}$ & $\begin{array}{l}\text { Forskolin (16h) } \\
\text { 8-Br-cAMP }(2 h)\end{array}$ & $\begin{array}{l}16751804 \\
14532334\end{array}$ & $\begin{array}{l}\text { Wang et al, } 2006 \\
\text { Tierney et al, } 2003\end{array}$ \\
\hline PTEN & 123 & & 4.092 & 26 & 4.635 & 1.858 & Endometrial cancer cell line (HEC-151) & $\begin{array}{l}\text { Infection by adenoviral PTEN Dominant } \\
\text { negatif }\end{array}$ & 11325847 & $\begin{array}{l}\text { Matsushima-Nishiu et } \\
\text { al, } 2001\end{array}$ \\
\hline $\begin{array}{l}\text { PTEN } \\
\text { translation }\end{array}$ & 92 & & 3.235 & & 1.708 & & $\begin{array}{l}\text { Polysom microarray analysis of U87MG glio } \\
\text { PTEN and treated by rapamycin }\end{array}$ & blastoma cell line transfected with wild-type & 14576155 & Gera et al, 2004 \\
\hline Rac1 & 34 & 23 & 1.369 & 7 & 1.964 & & $\begin{array}{l}\text { Colorectal adenocarcinoma } \\
\text { cell line (SW620) }\end{array}$ & $\begin{array}{l}\text { Stably transfected shRNA versus wild type } \\
\text { Rac1 }\end{array}$ & 17766170 & $\begin{array}{l}\text { Gomez del Pulgar et al, } \\
2007\end{array}$ \\
\hline TSC1/2 & 41 & 27 & & 0 & 1.461 & 1.8 & & Transient TSC $1 / 2$ overexpression & 12894220 & Rosner et al, 2003 \\
\hline Wnt/bCAT & 222 & 142 & 3.399 & 31 & 2.867 & & $\begin{array}{l}\text { Neuroblastoma cell line (HeLa) } \\
\text { Database } \\
\text { Hepatoma carcinoma cell lines with constitut } \\
\text { (HepG2, SNU-182, SNU-354 versus Hep3B, }\end{array}$ & $\begin{array}{l}\text { Stably integrated, inducible RNA } \\
\text { interference (RNAi) for beta-catenin } \\
\text { tive versus minimal beta-catenin activity } \\
\text { PLC/PRF/5, SNU-387, SNU-449, SNU-475) }\end{array}$ & $\begin{array}{l}16959035 \\
\text { http://www.s } \\
\text { hways/targe } \\
17157329\end{array}$ & $\begin{array}{l}\text { Huang et al, } 2006 \\
\text { stanford.edu/ rnusse/pat } \\
\text { ets.html } \\
\text { Lee et al, } 2007\end{array}$ \\
\hline
\end{tabular}


Table S4: Nomenclature, primers and experimental conditions designed for real-time analysis of human gene transcription. Standards corresponding to fragments of human genes used as at several known concentrations were used to calibrate mRNA quantifications.

\begin{tabular}{|c|c|c|c|c|c|c|}
\hline Symbol & Name & Gene Id & Primers & $\begin{array}{c}\text { Hybridization } \\
\left({ }^{\circ} \mathrm{C}\right)\end{array}$ & $\begin{array}{l}\text { Amplicon } \\
\text { size (bp) }\end{array}$ & Standard \\
\hline \multirow{2}{*}{ ADIPOR1 } & \multirow{2}{*}{ Adiponectin receptor 1} & \multirow{2}{*}{51094} & Sens: 5' AAGCACCGGCAGACAAGAGC & \multirow[t]{2}{*}{60} & \multirow[t]{2}{*}{133} & \multirow[t]{2}{*}{ ADIPOR1 } \\
\hline & & & Antisens: 5' AGGAAGAACCAGCCCATCTG & & & \\
\hline \multirow{2}{*}{ ADIPOR2 } & \multirow{2}{*}{ Adiponectin receptor 2} & \multirow{2}{*}{79602} & Sens: 5' CTGTGTGCTGGGCATTGCAG & \multirow[t]{2}{*}{60} & \multirow[t]{2}{*}{180} & \multirow[t]{2}{*}{ ADIPOR2 } \\
\hline & & & Antisens: 5' AGCCTATCTGCCCTATGGTG & & & \\
\hline \multirow{2}{*}{ AFP } & \multirow{2}{*}{ Alpha fetoprotein } & \multirow{2}{*}{174} & Sens: 5' TCTCAGGCCTGTTGGAG & \multirow[t]{2}{*}{60} & \multirow[t]{2}{*}{98} & HPRT1 \\
\hline & & & Antisens: 5' CCAAAGCAGCACGAGTT & & & \\
\hline BHLHB2 I & Basic helix-loop-helix domain & 8552 & Sens: 5'CTGAGCAGAACATCTCTTGAC & 60 & 154 & BHLHB2 \\
\hline BHLHE40 & containing, class B, 2 & 8552 & Antisens: 5'GCAGTGGTTCTTGAACTTACC & & & \\
\hline CEBPA & CCAAT/enhancer binding protein & & Sens: 5'TGCCCATGGCCTTGACCAAGGAG & 60 & 254 & CEBPA \\
\hline & & 1050 & Antisens: 5'GCAAGGCCAAGAAGTCGGTGGAC & & & \\
\hline CEBPB & CCAAT/enhancer binding protein & 1051 & Sens: 5'GCTTGAACAAGTTCCGCAGG & 60 & 156 & CEBPB \\
\hline & & & AACATCGCCGTGCGCAAGAG & & & \\
\hline CDKN1B & $\begin{array}{l}\text { Cyclin-dependent kinase inhibitor 1B } \\
\text { (p27, Kip1) }\end{array}$ & 6043 & Sens: 5'GCAATGCGCAGGAATAAG & 60 & 135 & HPRT1 \\
\hline & & & AGGCTTCTTGGGCGTCT & & & \\
\hline CREBBP & CREB binding protein (Rubinstein- & 1387 & Sens: 5'CAAACGCCTTGTCCAGCATC & 58 & & CREBBP \\
\hline & & & Antisens: 5'GCCGTTTACCATGAGATCC & & & \\
\hline CYP19A1 & cytochrome P450, family 19 & 1588 & Sens: 5'ACGTGGTCAGAGTAGAACCC & 60 & 179 & HPRT1 \\
\hline & & & Antisens:GGTGTTTGGAAAGTTCCTCC & & & \\
\hline EGR1 & Early growth response 1 & 1958 & Sens: 5'GTTGTTCAGAGAGATGTCAGG & 60 & 88 & EGR1 \\
\hline & & & Antisens: 5'CAGCACCTTCAACCCTCAG & & & \\
\hline FABP1 & fatty acid binding protein 1 , liver & 2168 & Sens: 5'GCTGGAGACAATGACAGG & 62 & 125 & HPRT1 \\
\hline & & & Antisens: 5'CATTGGTGATTATGTCGCC & & & \\
\hline FOXM1/HNF3a & forkhead box M1 & 2305 & Sens: 5'TTCTTTAGTGGCGATCTGCG & 60 & 111 & HPRT1 \\
\hline & & & Antisens: 5'AAGAAAGAGGAGCTATCCCCTC & & & \\
\hline F0X01A & forkhead box 01 & 2308 & Sens: 5'AGACATCTTTGGACTGCTTC & 60 & 115 & FOXO1A \\
\hline & & & Antisens: 5'TCAAGACAACGACACATAGC & & & \\
\hline HES1 & hairy and enhancer of split 1 , & 3280 & Sens: 5' GAAATGACAGTGAAGCACCTC & 55 & 113 & HPRT1 \\
\hline & (Drosophila) & 3280 & Antisens: 5' GTTCATGCACTCGCTGAAG & & & \\
\hline HIF1A & $\begin{array}{l}\text { hypoxia inducible factor } 1 \text {, alpha } \\
\text { subunit (basic helix-loop-helix }\end{array}$ & 3091 & Sens: 5'GCTTTGCAGAATGCTCAGAG & 60 & 98 & HPRT1 \\
\hline & transcription factor) & & Antisens: 5'TGATCGTCTGGCTGCTGT & & & \\
\hline HK2 & Hexokinase 2 & 3099 & Sens: 5'TGTTGCAGGATGGCTCGGAC & 60 & 131 & HK2 \\
\hline & & & Antisens: 5'CAAGCGTGGACTGCTCTTCC & & & \\
\hline HNF4A & hepatocyte nuclear factor 4 , alpha & 3172 & Sens: 5'GAGATCCATGGTGTTCAAGG & 60 & 150 & HPRT1 \\
\hline & & & Antisens: 5'ATTGTCATCGATCTGCAGC & & & \\
\hline דסחע & hypoxanthine & (2)Г & Sens: 5' TTGCTGACCTGCTGGATTAC & 60 & 151 & HPRT1 \\
\hline HPRT & phosphoribosyltransferase 1 & 3251 & Antisens: 5' AGTTGAGAGATCATCTCCAC & & & \\
\hline IKBKAP & inhibitor of kappa light polypeptide & 8518 & Sens: 5' CAGCAACAGAAGACTTCGG & 58 & 95 & HPRT1 \\
\hline & $\begin{array}{l}\text { gene enhancer in Bcells, Kinase } \\
\text { complexassociated protein }\end{array}$ & & Antisens: ATCTAGCAGGCTCAGCTTC & & & \\
\hline IRF1 & interferon regulatory factor 1 & 3659 & Sens: 5'GCTGGGACATCAACAAG & 58 & 119 & HPRT1 \\
\hline & & & Antisens: 5'AAAGTTGGCCTTCCACGT & & & \\
\hline LDLR & low density lipoprotein receptor & 3949 & Sens: 5'TCACTCCATCTCAAGCATCG & 60 & 149 & HPRT1 \\
\hline & & & Antisens: 5'TGGCACTGAAAATGGCTTCG & & & \\
\hline MYc & v-myc myelocytomatosis viral & 4609 & Sens: 5'GTAGTTGTGCTGATGTGTGG & 60 & 171 & MYC \\
\hline & & & Antisens: 5'GAGGAGGAACAAGAAGATGAG & & & \\
\hline PPARG & Peroxisome proliferator-activated & 5468 & Sens: 5'GCATTATGAGACATCCCCAC & 65 & 474 & PPAR \\
\hline & & & Antisens: 5'TCTCTCCGTAATGGAAGACC & & & \\
\hline PPARGC1A & Peroxisome proliferator-activated & 10891 & Sens: 5'CTTGGTTGGCTTTATGAGGAGG & 60 & 143 & PPARGC1A \\
\hline & receptor gamma, coactivator 1 alpha & & Antisens: 5'TCCTCTGACCCCAGAGTCAC & & & \\
\hline TRP & TATA hox hinding nrotein & 6908 & Sens: 5' TGGTGTGCACAGGAGCCAAG & 60 & 139 & TBP \\
\hline & & & Antisens: 5' TTCACATCACAGCTCCCCAC & & & \\
\hline TGFB1 & Transforming growth factor, beta 1 & 7040 & Sens: 5'GGTTATGCTGGTTGTACAGG & 55 & 229 & TGFB \\
\hline & & & Antisens: 5'AGGGCTACCATGCCAACTTC & & & \\
\hline THBS1 & thrombospondin 1 & 7057 & Sens: 5'CTACAGATGGCGTCTCAGC & 60 & 126 & HPRT1 \\
\hline & & & Antisens: 5'CCCTAGTCTACCACCAGCATAG & & & \\
\hline TNFRSF1A & Tumor necrosis factor receptor & 7132 & Sens: 5'CAATCTGGGGTAGGCACAAC & 60 & 129 & TNFRSF1A \\
\hline & & & Antisens: 5'CCTGCCAGGAGAAACAGAAC & & & \\
\hline
\end{tabular}


Table S5: Real-time quantification of gene expression in HepG2 cells incubated with specific inhibitors during 5 hours in serum free standard media. Fold changes for samples treated versus controls (i.e. vehicle) were normalized to HPRT1. Significant modulation was considered through ANOVA test, i.e. $p$-value $<0.01(n>3$ independant experiments). Gene names, sequence references and primers are reported in Table S4, drug informations in Table S2.

\begin{tabular}{|c|c|c|c|c|c|c|c|c|c|}
\hline \multicolumn{3}{|c|}{ Genes up-regulated } & \multicolumn{3}{|c|}{ Genes down-regulated } & \multicolumn{4}{|c|}{ Genes not modulated } \\
\hline \multicolumn{10}{|c|}{ Gi/G0 (Inhibition by Pertussis Toxin, $500 \mathrm{ng} / \mathrm{ml}$ ) } \\
\hline CEBPA & -1.96 & \pm 0.03 & BHLHB2 & 2.77 & \pm 0.10 & ADIPOR1 & 1.01 & \pm & 0.05 \\
\hline \multirow[t]{9}{*}{ CREBBP } & -1.37 & \pm 0.09 & HES1 & 2.47 & \pm 0.10 & AFP & 1.02 & \pm & 0.06 \\
\hline & & & HNF4A & 2.23 & \pm 0.38 & CEBPB & 0.93 & \pm & 0.04 \\
\hline & & & TGFB1 & 1.80 & $\pm \quad 0.02$ & CYP19A1 & 1.03 & \pm & 0.16 \\
\hline & & & THBS1 & 1.69 & \pm 0.20 & EGR1 & 0.95 & \pm & 0.01 \\
\hline & & & FOXM1/HNF3 & 1.54 & $\pm \quad 0.11$ & FABP1 & 1.31 & \pm & 0.08 \\
\hline & & & ADIPOR2 & 1.49 & $\pm \quad 0.05$ & IKBKAP & 0.84 & \pm & $0 / 04$ \\
\hline & & & IRF1 & 1.48 & $\pm \quad 0.05$ & PPARG & 1.17 & \pm & 0.09 \\
\hline & & & LDLR & 1.44 & $\pm \quad 0.02$ & TBP & $0 / 98$ & \pm & 0.06 \\
\hline & & & TNFRSF1A & 1.44 & $\pm \quad 0.07$ & & & & \\
\hline \multicolumn{10}{|c|}{ Mek1/2 (Inhibition by U0126, $10 \mu \mathrm{M})$} \\
\hline CEBPA & -1.75 & 0.02 & IRF1 & 3.31 & $\pm \quad 0.67$ & ADIPOR1 & 1.21 & \pm & 0.05 \\
\hline EGR1 & -1.59 & 0.07 & FOX01A & 1.57 & 0.10 & ADIPOR2 & -1.09 & \pm & 0.04 \\
\hline HK2 & -1.53 & 0.02 & CYP19A1 & 1.45 & 0.06 & AFP & 1.18 & \pm & 0.08 \\
\hline LDLR & -1.44 & 0.02 & HES1 & 1.42 & 0.03 & BHLHB2 & -1.13 & \pm & 0.02 \\
\hline \multirow[t]{12}{*}{ MYC } & -1.38 & 0.03 & & & & CEBPB & -1.08 & \pm & 0.13 \\
\hline & & & & & & CREBBP & 1.15 & \pm & 0.13 \\
\hline & & & & & & FABP1 & 1.21 & \pm & 0.07 \\
\hline & & & & & & FOXM1/HNF3 & 1.28 & \pm & 0.06 \\
\hline & & & & & & HNF4A & 1.20 & \pm & 0.07 \\
\hline & & & & & & IKBKAP & -1.18 & \pm & 0.07 \\
\hline & & & & & & PPARG & 1.31 & \pm & 0.10 \\
\hline & & & & & & PPARGC1A & 1.31 & \pm & 0.14 \\
\hline & & & & & & TBP & 1.23 & \pm & 0.05 \\
\hline & & & & & & TGFB1 & -1.22 & \pm & 0.12 \\
\hline & & & & & & THBS1 & -1.04 & \pm & 0.03 \\
\hline & & & & & & TNFRSF1A & 1.07 & \pm & 0.17 \\
\hline \multicolumn{10}{|c|}{ P42/44 (inhibition by A6355, $90 \mu \mathrm{M}$ ) } \\
\hline CEBPA & -8.07 & 0.00 & EGR1 & 17.34 & $\pm \quad 0.39$ & ADIPOR1 & 1.23 & \pm & 0.06 \\
\hline PPARGC1A & -2.31 & 0.05 & LDLR & 6.63 & 0.44 & CEBPB & 1.06 & \pm & 0.13 \\
\hline MYC & -2.15 & 0.05 & BHLHB2 & 5.84 & 0.11 & FABP1 & 1.29 & \pm & 0.06 \\
\hline CREBBP & -2.10 & \pm 0.04 & HES1 & 3.98 & 0.09 & HK2 & 1.07 & \pm & 0.05 \\
\hline IKBKAP & -2.09 & 0.00 & FoX01A & 2.93 & 0.42 & TBP & 1.02 & \pm & 0.04 \\
\hline HNF4A & -1.62 & $\pm \quad 0.04$ & IRF1 & 2.17 & 0.15 & TGFB1 & 1.29 & \pm & 0.16 \\
\hline THBS1 & -1.48 & $\pm \quad 0.07$ & CYP19A1 & 1.94 & 0.17 & & & & \\
\hline TNFRSF1A & -1.40 & $\pm \quad 0.08$ & ADIPOR2 & 1.92 & 0.05 & & & & \\
\hline AFP & -1.38 & $\pm \quad 0.04$ & FOXM1/HNF3 & 1.89 & 0.11 & & & & \\
\hline & & & PPARG & 1.45 & $\pm \quad 0.12$ & & & & \\
\hline \multicolumn{10}{|c|}{ PKC (Inhibition by P3115, $50 \mu \mathrm{M}$ ) } \\
\hline \multirow[t]{10}{*}{ CEBPA } & -2.17 & 0.03 & BHLHB2 & 3.85 & $\pm \quad 0.07$ & ADIPOR1 & 1.08 & \pm & 0.03 \\
\hline & & & LDLR & 3.23 & 0.78 & AFP & -1.24 & \pm & 0.08 \\
\hline & & & HES1 & 2.50 & 0.05 & CEBPB & -1.22 & \pm & 0.07 \\
\hline & & & THBS1 & 2.00 & 0.32 & CREBBP & -1.33 & \pm & 0.01 \\
\hline & & & HNF4A & 1.83 & 0.08 & FABP1 & 1.16 & \pm & 0.06 \\
\hline & & & EGR1 & 1.67 & 0.09 & FOXO1A & 1.23 & \pm & 0.16 \\
\hline & & & MYC & 1.61 & 0.10 & TBP & 1.01 & \pm & 0.06 \\
\hline & & & FOXM1/HNF3 & 1.57 & 0.20 & TGFB1 & 1.33 & \pm & 0.01 \\
\hline & & & ADIPOR2 & 1.50 & 0.07 & TNFRSF1A & 1.04 & \pm & 0.07 \\
\hline & & & PPARG & 1.44 & $\pm \quad 0.12$ & & & & \\
\hline \multicolumn{10}{|c|}{ JAK1 (Inhibition by Butein, $20 \mu M$ ) } \\
\hline & & & EGR1 & 2.8 & $\pm \quad 0.12$ & ADIPOR1 & 1.29 & \pm & 0.00 \\
\hline & & & BHLHB2 & 2.67 & 0.16 & ADIPOR2 & 1.26 & \pm & 0.01 \\
\hline & & & AFP & 2.33 & 0.10 & CEBPA & 1.18 & \pm & 0.09 \\
\hline & & & FOXM1/HNF3 & 2.31 & 0.03 & PPARG & -1.02 & \pm & 0.03 \\
\hline & & & CEBPB & 1.70 & 0.16 & TBP & 1.26 & \pm & 0.04 \\
\hline & & & HES1 & 1.64 & 0.02 & & & & \\
\hline & & & LDLR & 1.57 & 0.08 & & & & \\
\hline
\end{tabular}


Figure S1: Search of links between genes selected for mRNA qunatificatioon and (A) hepatic functions (B) hepatic disorders (C) canonical pathways as defined by Ingenuity Systems Library. Gene nomenclature is reported in Table S4.

\section{A-Healty liver}

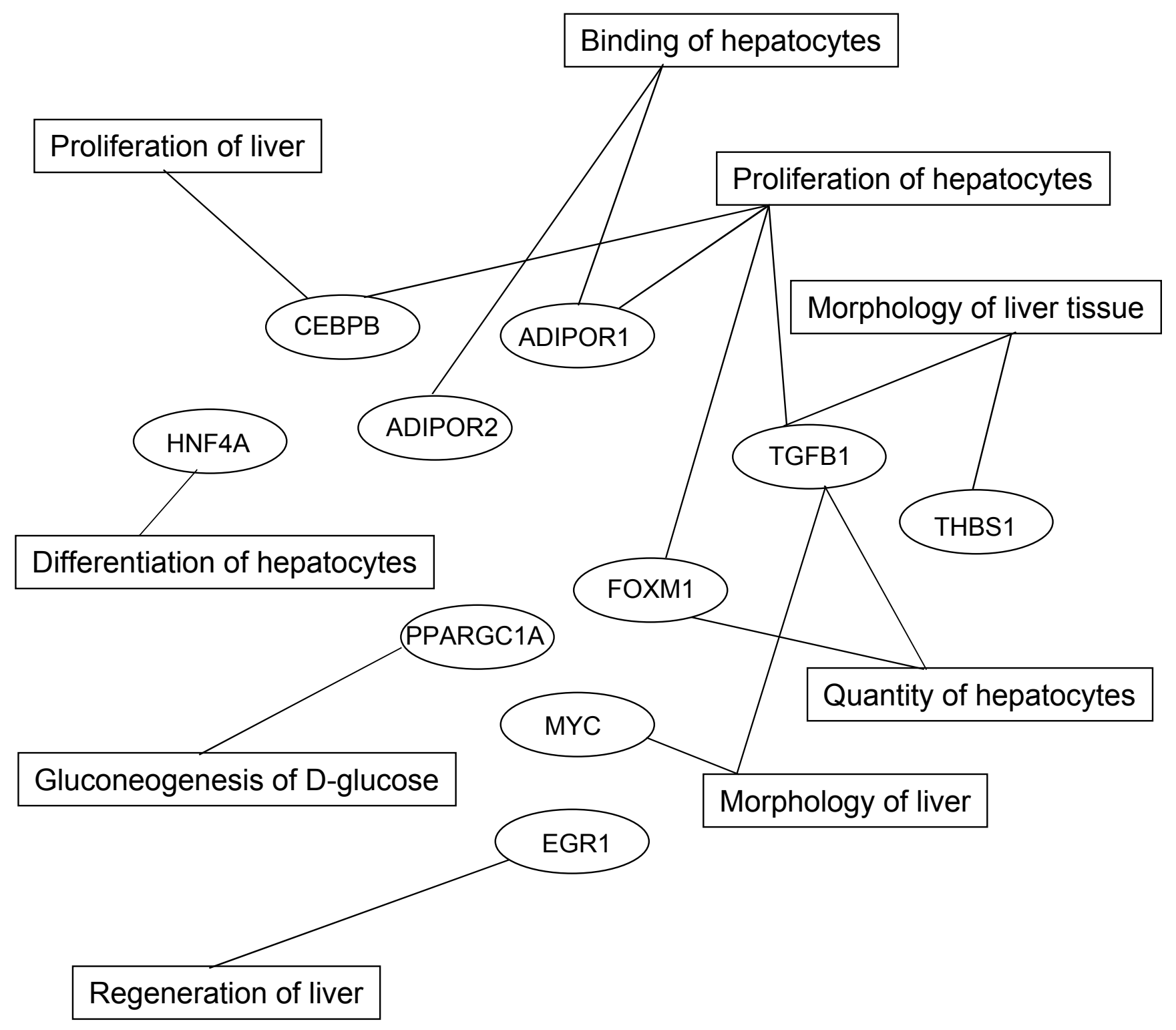




\section{B-Hepatic diseases}

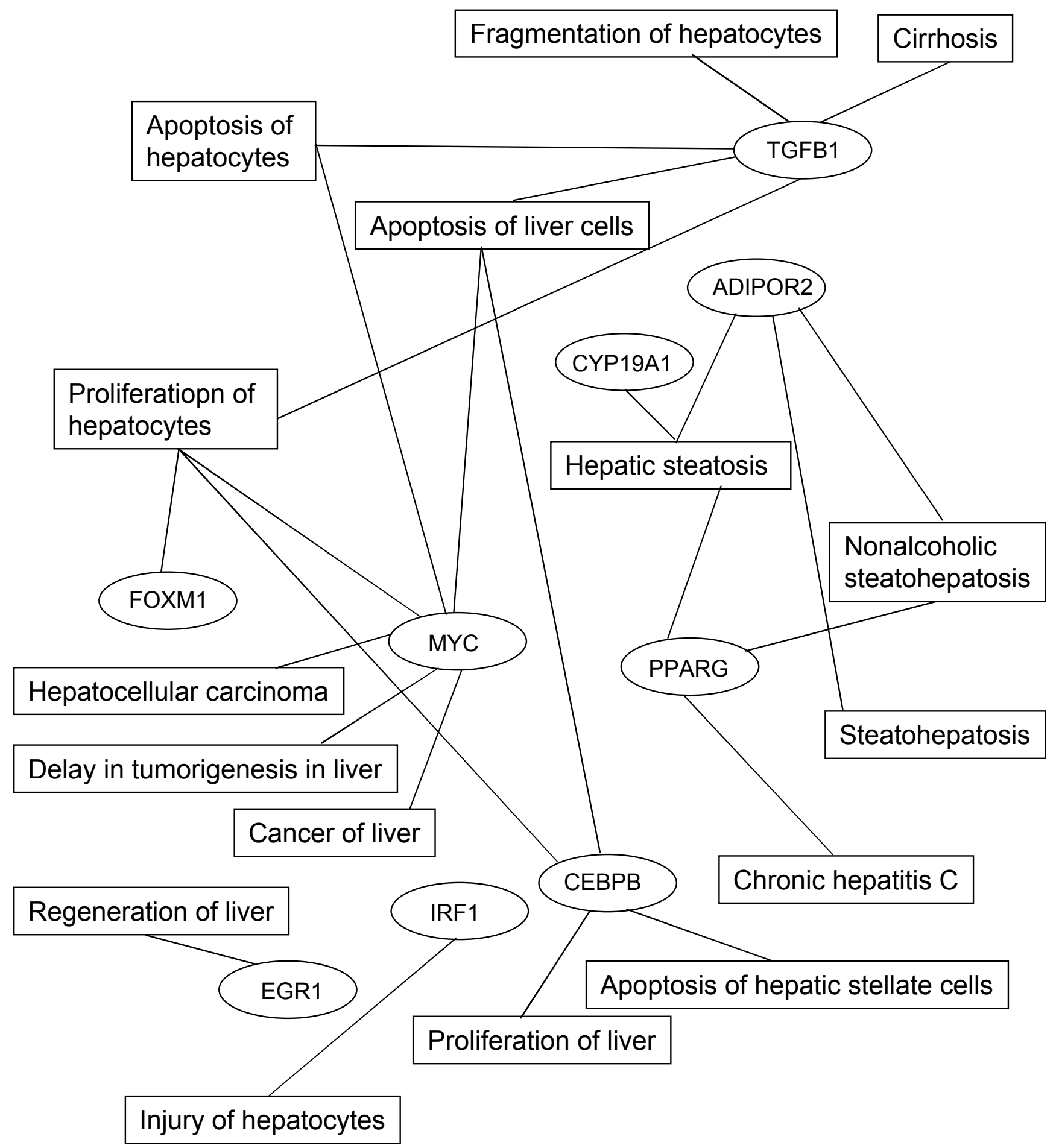




\section{C-Canonical pathways}

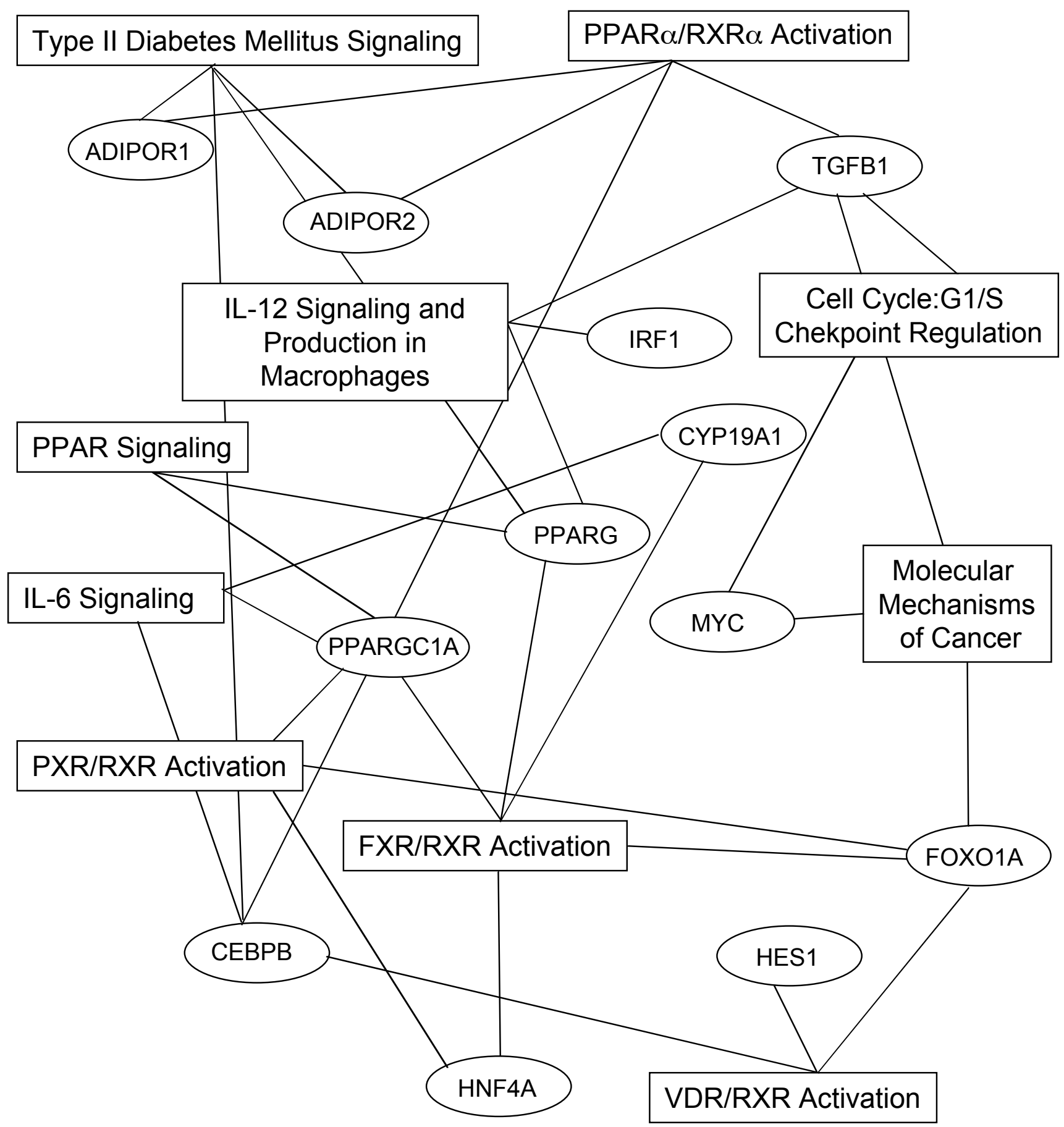


Figure S2: Real Time Cell Analysis of signaling pathways involved in cell growth and/or proliferation by using specific inhibitors on (A) HepG2 cells (B) HuH7 cells (during one day); name of pathways and concentrations are reported in Support. Information, Table S2. Left panel represents the cell index normalized at time of treatment, right panel corresponding slopes (representative experiments, mean values $+/-$ SEM, $n>6$; Student test t $p$-value $\left.{ }^{*}<0.05 ;{ }^{* *}<0.001 ;{ }^{* * *}<0.0001\right)$.

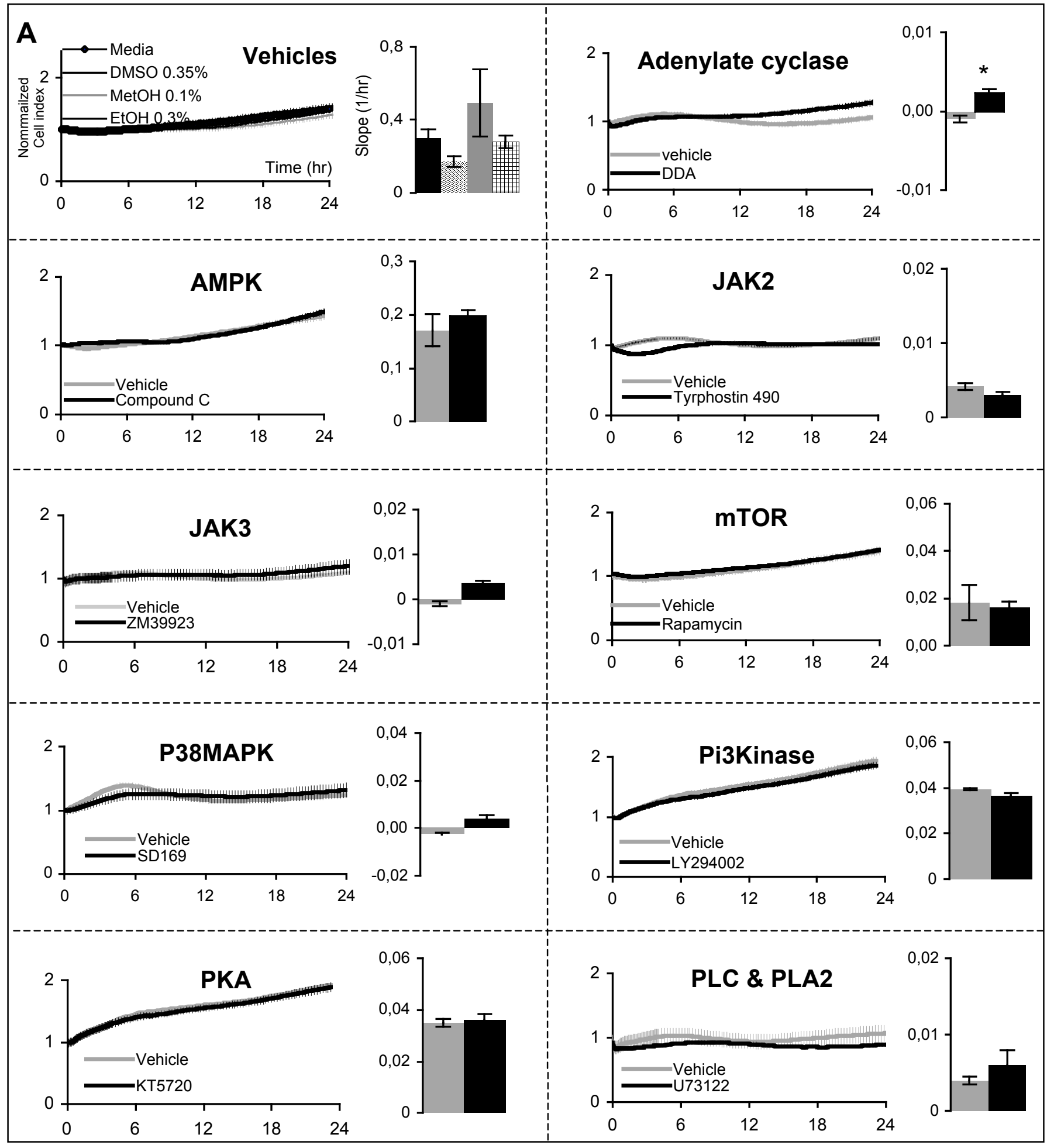


B

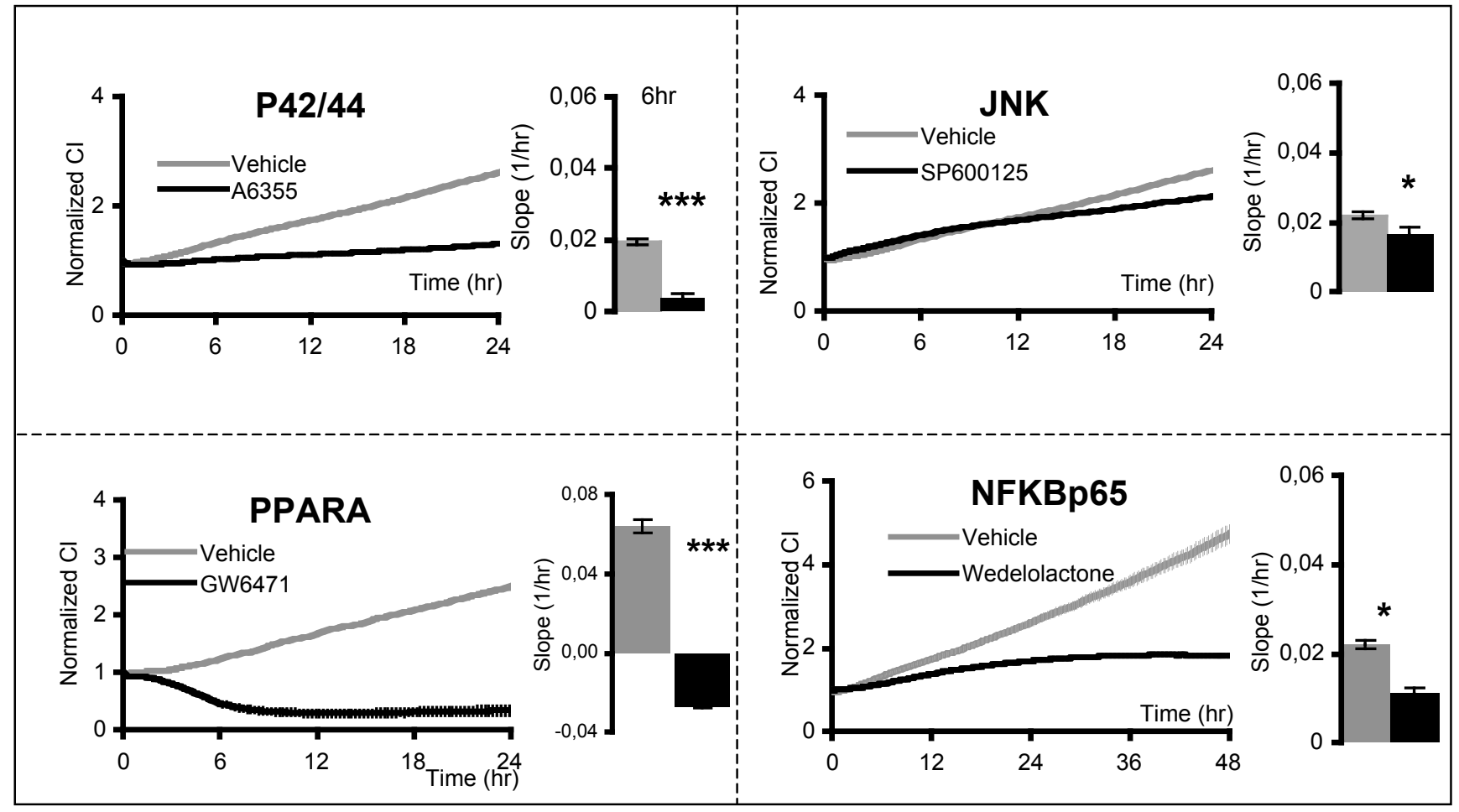




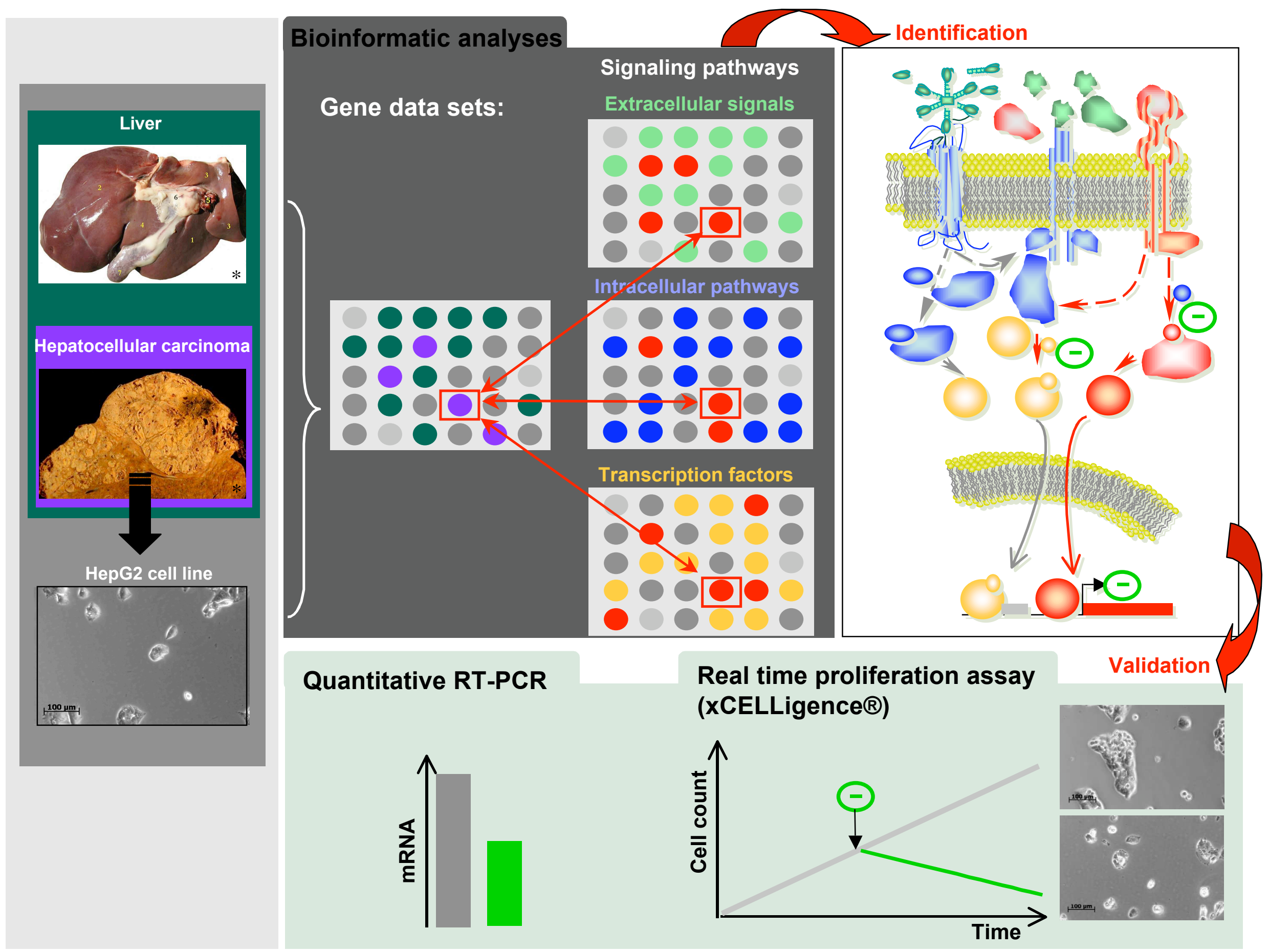




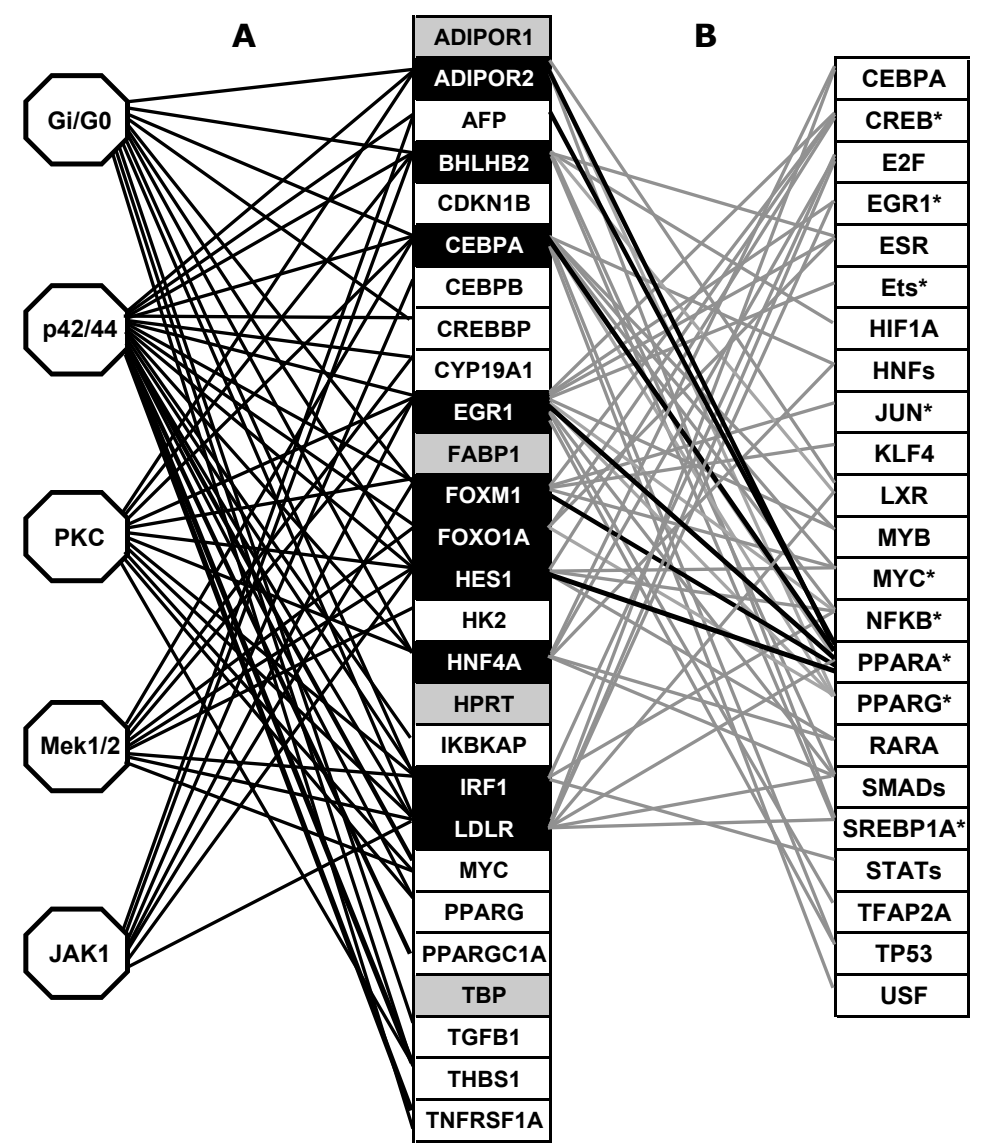




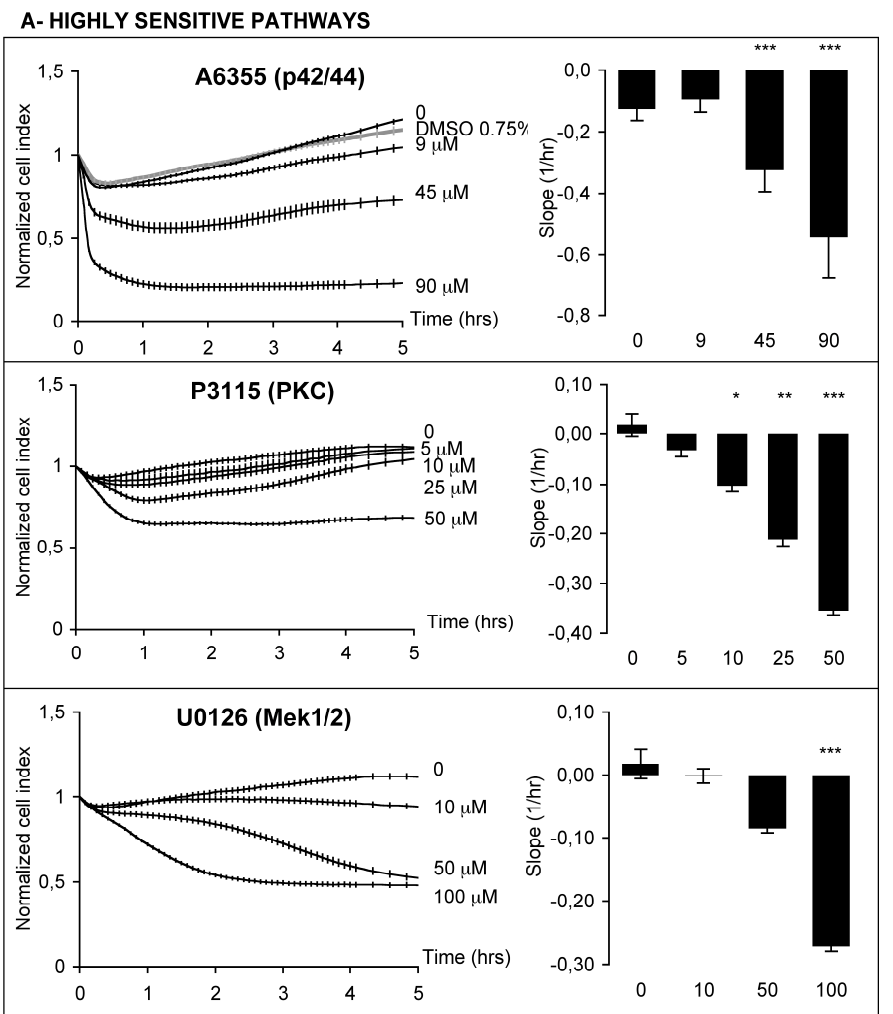

\section{B- SLIGHT SENSITIVE PATHWAYS}
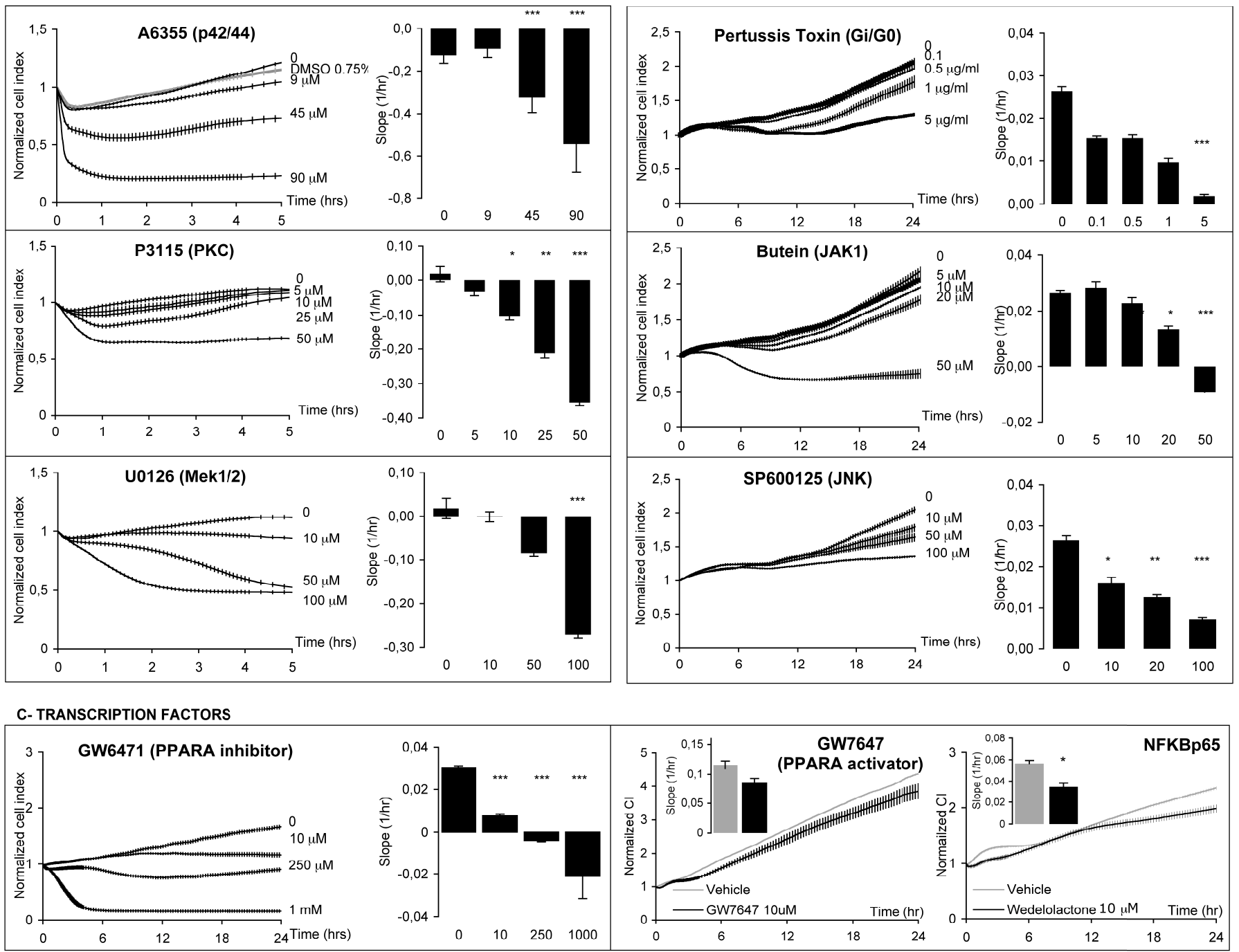


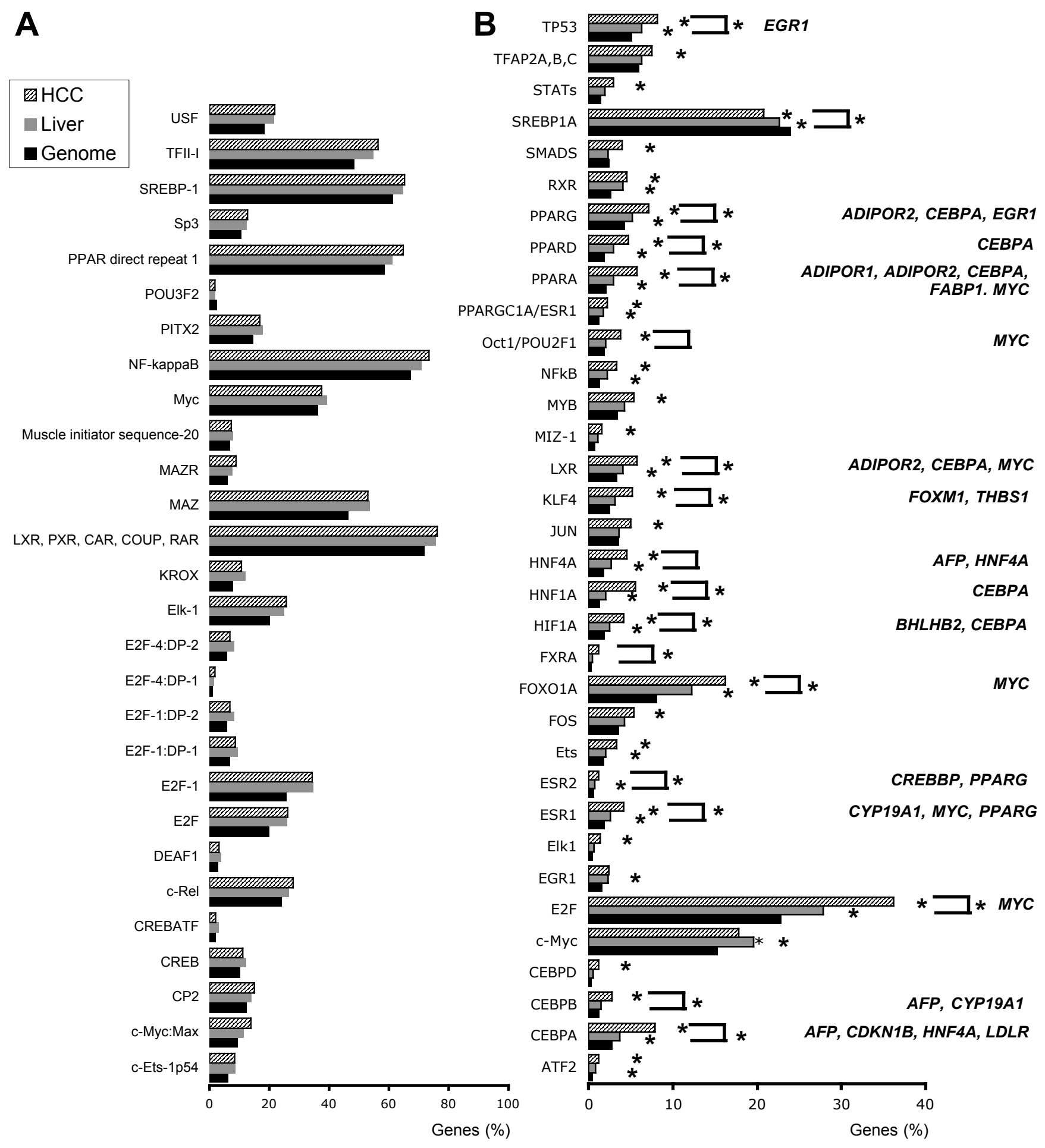




\section{A Stimulus}

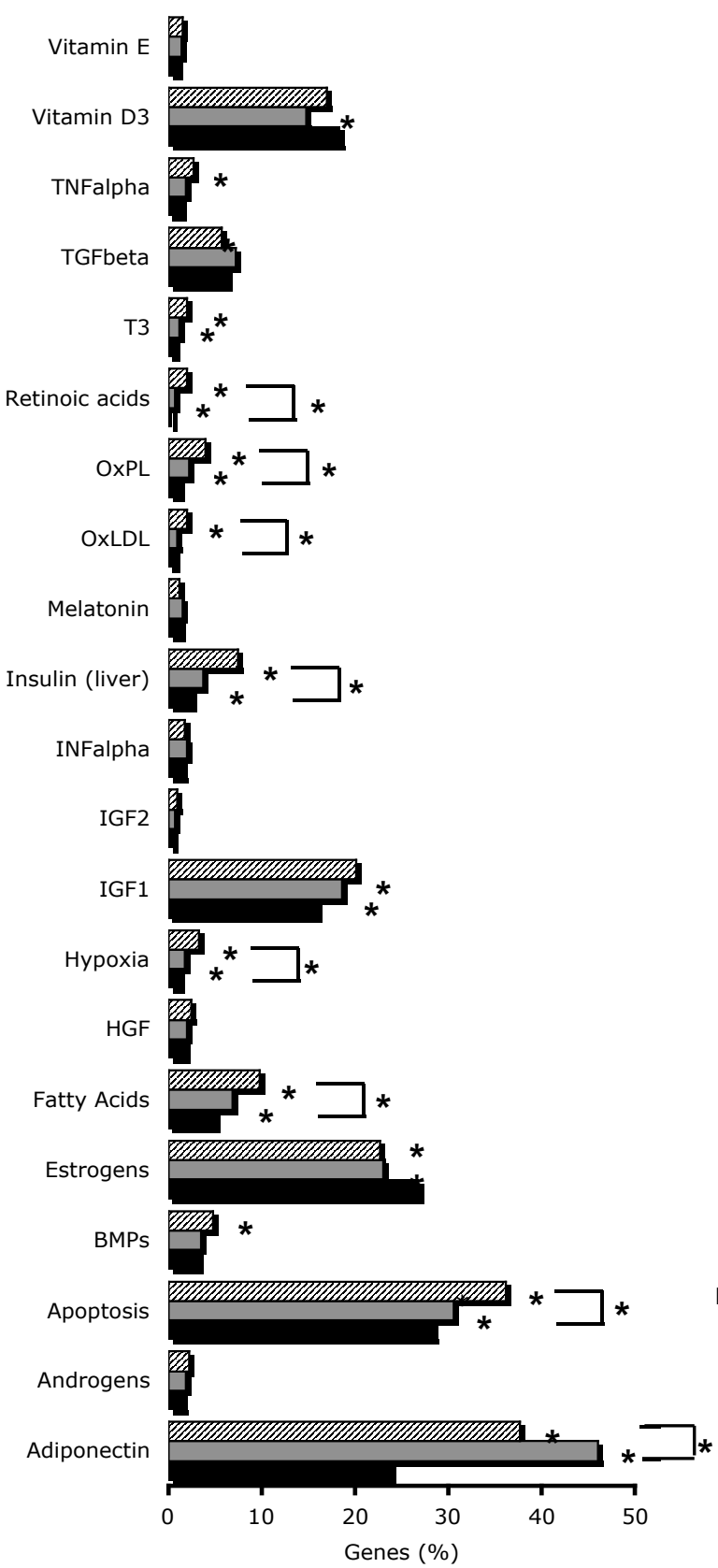

\section{B Intracellular pathways}

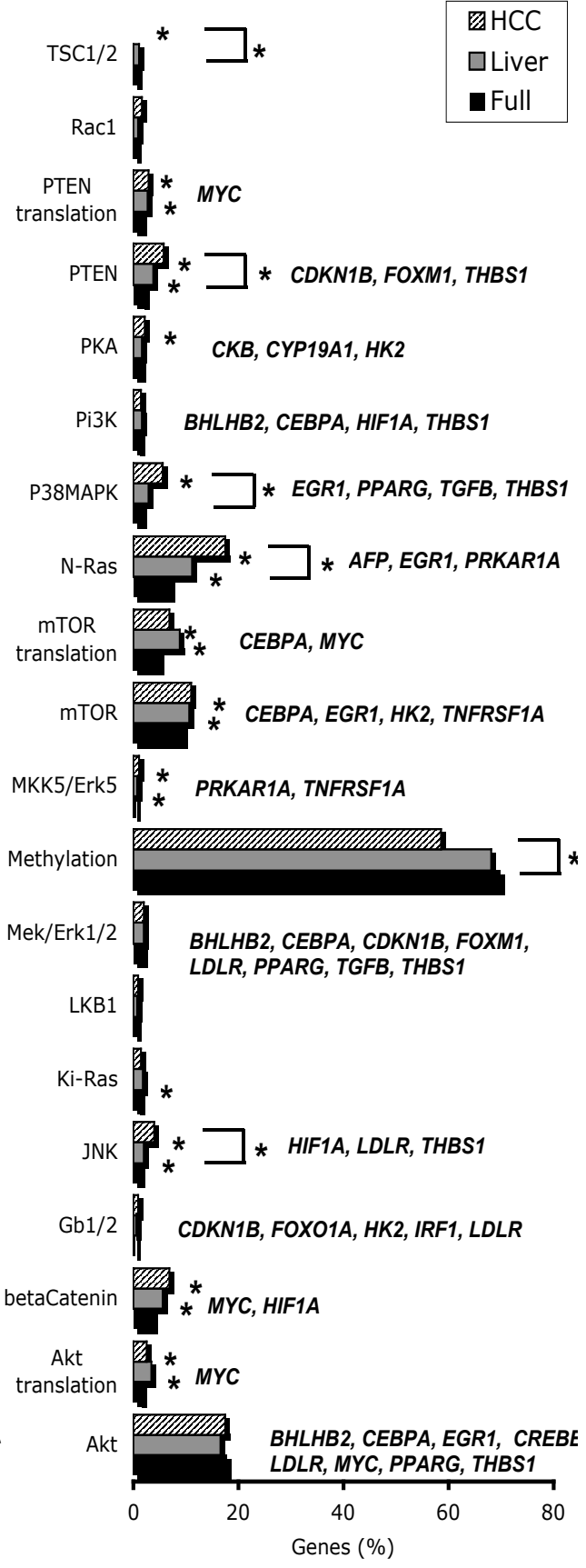


A

Stimulus

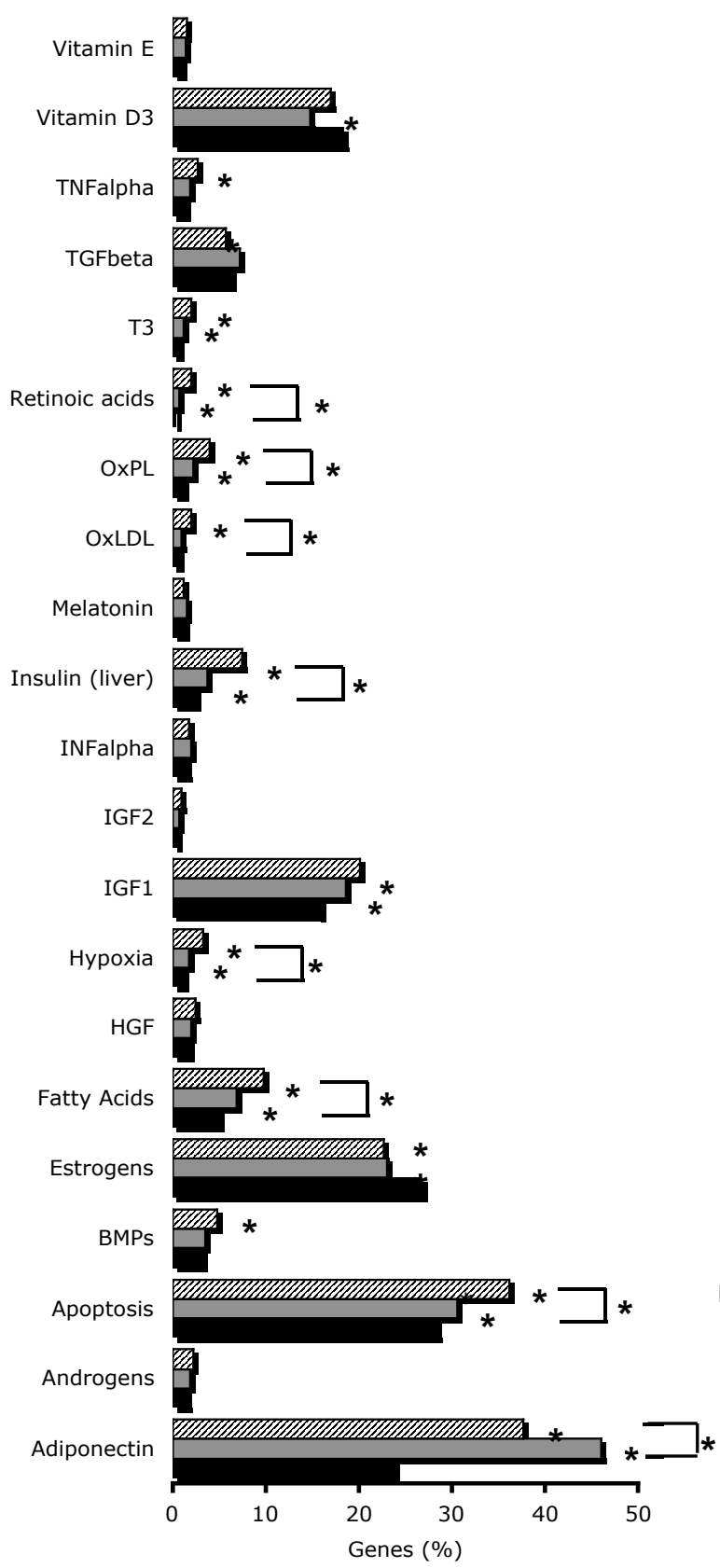

B Intracellular pathways

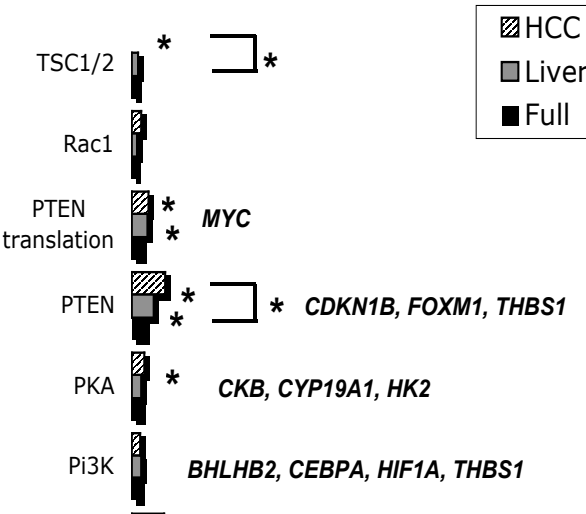

P38MAPK $*$ 可

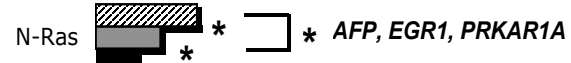

mTOR
translation
mTOR CEBPA, MYC

MKK5/Erk5 * PRKAR1A, TNFRSF1A

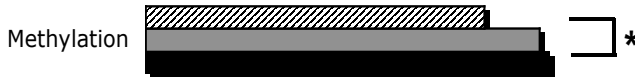

Mek/Erk1/2 BHLHB2, CEBPA, CDKN1B, FOXM1,

LKB1

Ki-Ras

JNK $\mathbb{F}_{*}^{*}$ Z H HF1A, LDLR, THBS1

Gb1/2 CDKN1B, FOXO1A, HK2, IRF1, LDLR

betaCatenin ${ }^{*}$ MYC, HIF1A

translation ${ }_{* \text { MYC }}^{\text {Akt }}$

Akt

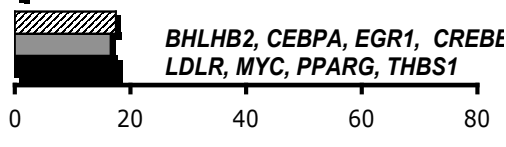




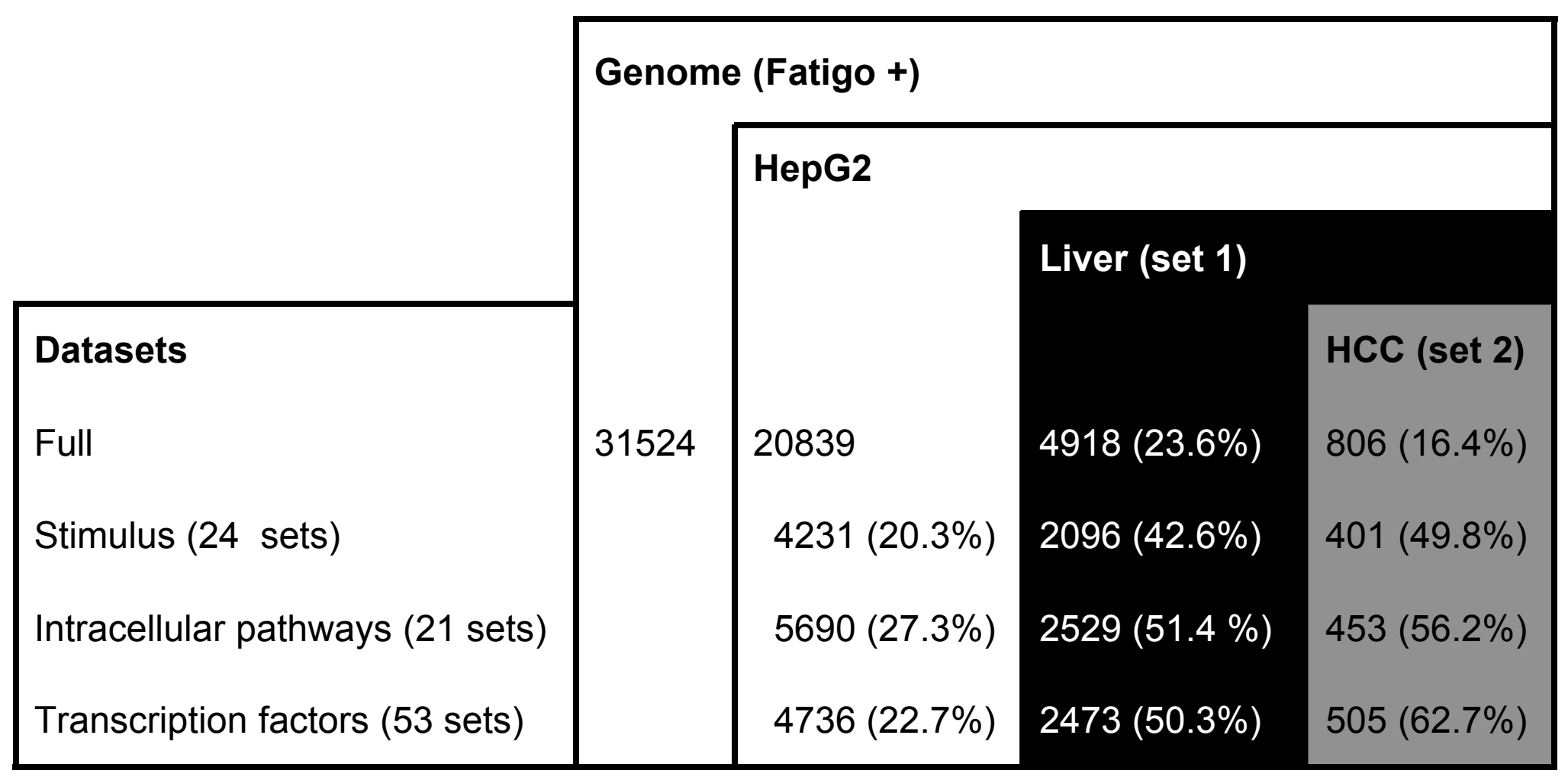




\section{Research Article}

Gene network analysis leads to functional validation of pathways linked to cancer cell growth and survival.

\section{BERGER Emmanuelle}

VEGA Nathalie

VIDAL Hubert

\section{GELOËN Alain}

${ }^{1}$ Lyon University, INSERM, UMR1060, F-69008 ; INRA 1235, CarMeN Laboratory, INSALyon, Lyon, F69008 France.

\section{${ }^{*}$ Corresponding author:}

Dr Emmanuelle Berger, PhD

CarMeN Laboratory, INSA-Lyon, Lyon, F69008 France.

Mail: emmanuelle.danty@univ-lyon1.fr

Keywords: human hepatocellular carcinoma, signal transduction, real-time proliferation assay.

\section{Abbreviations:}

ADIPOR1 and 2, adiponectin receptors 1 and 2 ; AMPK , 5'-AMP-activated protein kinase; BHLHB2, basic helix-loop-helix family, member e40 cAMP responsive element binding protein 1 ; CAR, constitutive androstane nuclear receptor ; CEBPA, CCAAT/enhancer binding protein alpha; CEBPs, CCAAT/enhancer binding proteins ; COUP, chicken ovalbumin upstream promoter-transcription factor ; DMEM : Dubbelco's minimum essential media ; FCS : fetal calf serum, FOXM1, forkhead box M1; FOXO1A, forkhead box 01 ; GO, gene ontology ; HCC, hepatocellular carcinoma ; HES1, hairy and enhancer of split 1 ; HIF1A, hypoxia inducible factor 1 , alpha subunit ; HNF4A, hepatic nuclear factor 4-alpha; HPRT1 : hypoxanthine phosphoribosyltransferase 1 ; JAK, Janus kinase ; JNK, Jun-NH2 kinase ; KROX or EGR, early growth response factor; CREB, LXR, liver X nuclear receptor ; MAPK, mitogen activated protein kinase ; MYC, v-myc myelocytomatosis viral oncogene homolog ; NFKBp65, Nuclear factor kappa B p65 subunit; PKC, protein kinase C ; PPARA and G, peroxisome-proliferator activated receptors alpha and gamma ; PTEN, 
phosphatase and tensin homolog ; PXR, pregnane $X$ nuclear receptor ; RAR, retinoic acid receptor; ROS, reactive oxigen species ; RTCA: real-time cell analyser ; RT-

qPCR, real time quantitative polymerase chain reaction ; SREBP1, sterol regulatory element binding protein 1. 


\begin{abstract}
Hepatocellular carcinoma (HCC) represents one of the most frequent human cancers and efforts are needed to find alternative treatments to surgical resection, like intense screening of druggable targets. In this study we performed bioinformatic analyses of previously published transcriptomic data in order to characterize liver specific networks, i.e. biological functions, signaling pathways and transcription factors, potentially deregulated in HCC. Then, by using real-time proliferation assay with specific inhibitors, we validated the in silico results. We found that $\mathrm{G}$ protein subunits $\mathrm{Gi} / \mathrm{G} 0$, Protein kinase $\mathrm{C}$, mitogen activated kinases Mek1/2, and Erk1/2 (P42/44), Janus kinase JAK1, Peroxisome-proliferator activated receptors alpha (PPARA) and Nuclear factor kappa B p65 subunit, were the major signaling pathways required for survival and proliferation in human $\mathrm{HCC}$ cell lines. We also found that these pathways regulate the expression of key hepatic transcription factors involved in cell differentiation, such as CCAAT/Enhancer binding protein alpha (CEBPA), Early growth response factor (EGR1), Forkhead box M1 (FOXM1) and the PPARs. Thus, our study shows that the combination of bioinformatic analyses and functional analyses provided the opportunity to find the major signaling pathways related to tumorigenicity.
\end{abstract}




\section{Introduction}

Hepatocellular carcinoma (HCC) represents more than $80 \%$ of primary, malignant liver tumors and many efforts are needed to find alternative treatments to surgical resection, including intensive screening of druggable targets [1]. It is well established that $\mathrm{HCC}$ are characterized by major alterations in gene expression, mainly related to cell growth and maintenance, cell cycle and cell proliferation as well as metabolism [2-4]. Several signaling pathways are also affected, like Wnt and MAPK pathways [5-7] with elevated expression and activation of P42/44 (Erk1/2) [8-9] and reduced P38 MAPK activity [10] in HCC. In addition a number of other kinases at the crosstalk between cell growth, stress and metabolism have also been associated to hepatocarcinogenesis, such as the energy sensor AMPK [11], Pi3kinase [12] and JAK/STATs [13]. These alterations are potentially associated with deregulation of key transcription factors, such as CEBPs and HNF4A [14-15]. However, despite this important bulk of data, it is still difficult to draw a clear picture of the molecular mechanisms deregulated in HCC. Given the availability of large amount of data in public databases, our objective in the present study was to find the major cellular pathways deregulated in human HCC. To this aim, we first analysed previously published transcriptomic data of normal liver, in HCC and in HepG2 cells, in order to define the major biological functions, signaling pathways and transcriptions factors related to human HCC. Then, by using real-time proliferation assay in the presence of specific inhibitors of these signaling pathways, related to cell proliferation and/or survival, we validated the in silico approach in human HCC-derived cell lines.

\section{Materials and methods}

\subsection{Data analysis}

The sets of genes expressed in human normal liver, HCC and HepG2 cells were obtained from previous published studies (Supporting information, Table S1). Intracellular pathways or transcription factors modulated by various stimuli, were identified and retrieved from previously published experiments performed on different human cancer cell lines, and HepG2 cells (Supporting information, Table S2 and [16]).

Significantly over-represented biological functions were retrieved by using Fatigo+ software from http://babelomics.bioinfo.cipf.es. The putative transcription factors associated with these biological functions were found by using Fatigo+ software. Gene networks were built using the Ingenuity Systems Pathway analysis at www.ingenuity.com. The online TRED database was used to define the potential target genes for relevant transcription factors at http://rulai.cshl.edu/cgi-bin/TED/tred.cgi?process=home. 


\subsection{Cell culture, treatments and analyses}

The human hepatocarcinoma-derived cell lines HepG2 and $\mathrm{HuH} 7$ were provided from the European Collection of Cell Cultures (ECACC, Salisbury, UK). HepG2 cell line originated from human $\mathrm{HCC}$ is widely used as in vitro model to study hepatic functions as well as their deregulations in hepatic disorders. Cells were grown at $37^{\circ} \mathrm{C}$ in $5 \% \mathrm{CO} 2$ in DMEM containing $10 \%$ fetal calf serum, complemented with streptomycin $(100 \mathrm{mg} / \mathrm{ml})$ and penicillin (100 units $/ \mathrm{ml}$ ). Cell proliferation and/or survival was monitored with the xCELLigence Realtime Cell Analyser (RTCA) System (Roche Diagnosis, Meylan, France), which allows labelfree monitoring changes of cell number, viability, morphology and quality of cell attachment by measurement of cell-to electrode responses of cells seeded in E96-well plates manufactured with integrated microelectronic sensor arrays. Analyses were first performed to select accurate plating density (10 000 cells per well), reaching stable proliferation rate within one day (cell index 0.5 to 1 ). For signaling pathway analyses, specific inhibitors were applied in serum-free media one day after plating. Drug concentrations were optimized for each compound according to IC50 and dose-response analyses (Supporting information, Table S3). As we found that HepG2 cells are highly sensitive to serum deprivation, we had to adapt the conditions to maintain cells in stable proliferating rate and thus the duration of the treatments was limited (not more than 24 hours) when studying the effects of drugs and inhibitors. The results are representative of at least three independent experiments and each condition was tested in at least 5 replicates.

\subsection{Messenger RNA quantification by real time PCR}

Total RNA purifications from HepG2 cells were performed according to standard protocol (Qiagen Quick prep mRNA, Qiagen, Courtaboeuf, France) including a DNase treatment. RNA integrity was assessed with the Agilent 2100 Bioanalyzer and RNA 6000 LabChip Kit (Agilent Technologies, Massy, France). First strand cDNAs were synthesized from $500 \mathrm{ng}$ of total RNA in the presence of $100 \mathrm{U}$ of Superscript (Invitrogen-Life Technologies, Eragny, France) and random hexamers and oligodT primers (Promega, Charbonnières, France). Real-time PCR was performed using ABsolute ${ }^{\text {TM }}$ QPCR SYBR $®$ Green ROX Mix (Abgene, Courtaboeuf, France) with a Rotor-GeneTM 6000 system (Corbett Life Science, Cambridgeshire, UK). Levels of target mRNAs were normalized to hypoxanthine phosphoribosyltransferase 1 (HPRT1) expression measured in all samples by RT-qPCR. All quantifications were performed at least on three independent experiments and data are presented as mean \pm SEM. Gene names, references, functions, primers and respective qPCR conditions are reported in Supporting information, Table S4. 


\section{Results}

\subsection{Bioinformatic analysis of hepatic genes related to normal and HCC phenotypes.}

We first define a list of genes commonly expressed in HepG2 cell line and in human normal liver (Figure 1) from published global transcriptomic data. Then, we selected a second set of genes with altered expression in human HCC (806 genes). These two lists of genes were compared by using Fatigo + software in order to identify significantly enriched biological functions in human HCC. Figure 2A shows that they were linked to metabolism, cell proliferation and cell death. An analysis of biological processes over-represented in HCC versus hepatic HepG2 genes revealed a significant deregulation of genes involved in metabolism and coagulation (Figure 2B). Genes representative of these biological functions were selected for further analyses (Supporting information, Table S4). Using Ingenuity software, we constructed the relationships between genes involved liver functions (Supporting information, Figure S1A), hepatic diseases (Supporting information, Figure S1B) and in hepatic canonical pathways (Supporting information, Figure S1C). We found a number of links suggesting the implication of these genes in HCC and in liver cell proliferation and survival.

\subsection{Signaling pathways over-represented in set of genes deregulated in human HCC} We next identified by computational analyses, different groups of genes regulated by external stimuli (21 different conditions) or intracellular signaling pathways (20 different conditions) expressed in normal liver (gene set 1) but deregulated in HCC (gene set 2).

(Figure 3; references of gene sets are reported in Supporting information, Tables S2). We found that the list of genes deregulated in HCC is significantly enriched in genes also regulated by insulin, by fatty acids and adiponectin, by retinoic acids, by stress conditions (such as oxidized lipids and hypoxia) and during apoptosis. Furthermore, there is a specific enrichment in genes under the control of the Ras-coupled pathways Mek/Erk and P38MAPK, the JNK pathway and the PTEN/Pi3K pathway.

\subsection{Transcription factors regulating hepatic and HCC gene expression}

In order to determine the transcription network involved in hepatic function in HepG2 (set 1) and deregulated in HCC (set 2), we searched for transcription factors having putative binding sites in the promoter regions of these 2 sets of genes by using Fatigo+ software. Twenty-eight significant binding sites appeared to be over-represented in the promoter region of both sets in comparison to the human genome (Figure 4A) and are linked to transcription factors known to be involved in the regulation of cell cycle (E2Fs, MYC), to MAPK-regulated pathways (KROX, Elk1, CREB), to metabolic pathways, such as PPARs, 
SREBP1 and other nuclear receptors (LXR, PXR, CAR, COUP, RAR), and to inflammatory response (NFKB and c-Rel).

In order to determine whether the 28 transcription factors with significant over-represented binding sites in the promoter region of gene sets 1 and 2 were functional, we analysed the lists of genes regulated by 53 different transcription factors in human tissues (Figure 4B). This second approach thus took into account experimental data obtained mainly in cancer cell lines, including HepG2 cells, and have been previously published [16]. A set of 4736 genes (i.e. $22.7 \%$ of human genome) regulated by at least one of these transcription factors was retrieved, also regulating $50.3 \%$ of genes in set 1 and $62.7 \%$ in set 2 (Figure 1). We found an over-representation of genes regulated by 34 transcription factors in either normal liver or HCC gene sets, including CEBPs, E2Fs, EGR1, FOXO1A, HNFs, MYC, NFKB and PPARs. Importantly, 16 of these transcription factors regulate expression of genes present in HCC gene set, including hepatic genes regulated by CEPBA and CEBPB, FOXO1A, HNF4A, PPARs, steroid responsive transcriptions factors (ESR1 and 2, LXR), and stress and apoptosis linked transcription factors such as TP53 or HIF1A. NFKB and E2Fs.

\subsection{HepG2 cell growth, proliferation and survival depend on basal MAPK activities.}

We then investigated the potential implication of the signaling pathways identified by computational analyses (Figure 3) on hepatic cell growth, proliferation and survival. HepG2 cells were treated with a panel of specific kinase inhibitors and corresponding vehicles as controls (Supporting information, Table S3) and their growth was monitored with xCELLigence System using Real-time Cell Analyser (RTCA) Instrument. Cell indexes, which represent cell surface occupancy, and thus cell number, were normalized at time of treatment (one day after plating) and slopes of resulting curves were calculated after treatment (Figure 5 ; Supporting information, Figure S2). Among the 15 pathways explored, only 6 inhibitors were found to significantly affect HepG2 cell proliferation. Inhibition of adenylate cycle slightly but significantly increased HepG2 cell proliferation. HepG2 cell survival was affected in less than one hour in a dose-dependent manner by specific inhibitors of P42/44, PKC and Mek1/2 respectively (Figure 5A). HepG2 cell proliferation was found to be reduced after one day by specific inhibitors of Gi/G0 and JAK1 (not JAK2 and JAK3) and in a lesser extend JNK

(Figure 5B). Similar effects were observed for both P42/44 and JNK inhibitors when applied on $\mathrm{HuH} 7$ cells (Supporting information, Figure S2B).

\subsection{Characterization of genes and transcription factors linked to HepG2 cell proliferation and survival}

Finally, in order to experimentally validate the implication of the different signaling pathways identified, we measured the expression level of a selected number of genes expressed in 
HepG2 cells treated with specific inhibitors of either Gi/G0, P42/44, Mek1/2, PKC and JAK1 pathways. The whole RT-qPCR data are reported in Supporting information, Table S5. An integrative view of the results obtained by both computational analyses of gene data sets and RT-qPCR is provided in Figure 6. We found that ADIPOR2, BHLHB2, FOXM1, HES1 and LDLR were repressed and CEBPA was induced by basal activity of either Gi/G0, P42/44 and PKC. These 6 genes were further used to identify candidate transcription factors involved in their regulation. According to transcriptional data in human cells (cf Figure 4), these genes might be regulated by at least 23 types of transcription factors, 9 of them being involved in P42/44 signaling pathway (i .e CREB, EGR1, Ets, JUN, MYC, NFKB, PPARA and G, and SREBP1A), 4 of them could be regulated by CREB, NFKB, PPARA and PPARG. Interstingly, genes regulated by either NFKB, PPARA and PPARG are also over-represented in both normal liver and in HCC gene sets (cf Figure 4). As an example, we validated that PPARA, a major nuclear factor controlling hepatic metabolism, was a transcriptional activator of EGR1, FOXM1, HES1 and ADIPOR2, and inhibited CEBPA gene transcription in HepG2 cells (Table 1). RTCA monitoring revealed that PPARA specific inhibitor GW6471 significantly affected HepG2 survival in a dose-dependent manner, while its specific activator GW7647 had no significant effect (Figure $\mathbf{5 C}$ ). In addition, by using its specific inhibitor Wedelolactone we also found that NFKBp65 was required for HepG2 cell proliferation (Figure 5C). The effects of both GW6471 and Wedelactone were also observed on $\mathrm{HuH7}$ cell line (Supporting information, Figure S2B).

\section{Discussion}

In this study, we report the identification of transcription networks and signaling pathways involved in normal hepatic functions being deregulated in human HCC. These results were obtained by computational analyses of published data sets. They were then validated by using real-time cell proliferation assays on HepG2 cells treated by specific inhibitors of signaling pathways and by quantification of gene expression levels. The present study provides therefore a comprehensive global picture of the complex networks including specific signaling pathways, transcription factors and gene regulations potentially contributing to the proliferation of transformed liver cells. As expected, most of the major features already described in the literature were found and thus confirmed in this study, such as hepatic specialization in regulation of metabolism and deregulation of cell growth and survival pathways in HCC.

The process of tumorigenesis involves deregulations of pathways controlling cell growth, proliferation and survival in normal conditions. These are due to abnormal responses to external stimuli and/or to defective intracellular regulations of these pathways. Using computational analyses of published data sets obtained in human cells or tissues we 
identified biological pathways and gene networks over-represented in HepG2 and in HCC and we confirmed their implication in cell proliferation using Real-time cell Analyser Instrument (xCELLigence system).

Among the signaling pathways involved in HepG2 cell survival, which are either overexpressed or up-regulated in HCC, we identified PKC [17], P42/44 [10], Gi/G0 [18] as well as NFKBp65 [19] and JAK1 (but not JAK2 nor JAK3). JAK/STAT pathways are involved in the progression of cell cycle and to confer resistance to apoptosis [20, 21]. Our result can be explained by the fact that JAK1 inhibitor butein may also activate JNK and ROS production in HepG2 cells, leading to cell cycle arrest and apoptosis [22]. The lack of effect of the JAKs could be a consequence of the well described constitutive activation of STAT3 in most HCC as well as in HepG2 cells [23].

PKC is known to activate NFKB by isoform alpha and P42/44 by isoform beta in HCC [24]. In our study, NFKB was identified by both computational analyses of enriched transcription factor target genes and binding site enrichment in HepG2 and HCC. Moreover basal NFKBp65 activity appeared to be required for HepG2 cell growth. These results are in accordance with other studies showing that inhibition of NFKB as well as PKCalpha isoform in HepG2 cells can induce apoptosis [25] and that p65 subunit is involved in HepG2 cell survival $[26,27]$. The second pathway regulated by PKC is linked to P42/44. High levels of basal P42/44 activated form in HCC has been shown to involve the Ras/Mek/Erk/FOXM1 pathway [28]. We found here that P42/44 inactivation led to cell death in HepG2 and to cell cycle arrest in $\mathrm{HuH} 7$ cells. Moreover we found a regulation of FOXM1 gene expression by PKC and by P42/44 itself. In other studies, FOXM1 has been found to exert an anti-apoptotic activity in HCC and is up-regulated in liver cancer [29, 30]. P42/44 is known to regulate the activity of the transcription factor MYC, which was also regulated at the transcriptional level in HepG2 by both PKC and P42/44 pathways in our experiments. MYC is considered as a tumor suppressor because of its pro-apoptotic activity and its down-regulation in both HCC and liver cancers [31]. EGR1 is another tumor suppressor known to be regulated by the P42/44 signaling pathway. We found that inhibition of P42/44 activity in HepG2 cells strongly induced expression of EGR1 gene. In the same way, its transcription is down-regulated in HCC and liver cancers [32], suggesting that EGR1 may play important roles in liver cancers. PKC and P42/44 also regulate the transcriptional activity of nuclear receptors PPARs [33]. Whether the PPARs are involved in hepatocellular carcinogenesis remains elusive. In several studies, activation of PPARG has been shown to induce apoptosis in HepG2 cells [34-37] and to reduce tumor growth in $\mathrm{HCC}[38,39]$, and microarrays data suggest that PPARG may regulate BHLHB2, CEBPA, EGR1 and FOXO1A in HepG2 cells [40]. In the present study, we found that PPARA also regulates transcription of EGR1, FOXO1A and FOXM1. PPARA is highly expressed in liver where it is a key regulator of lipid metabolism 
and its regulatory activity on fatty acid oxidation has been established in HepG2 cells [41-43]. In both HepG2 and HuH7 cell lines we did not found any effect of PPARA activation on cell growth and/or survival, however its inactivation greatly affected their survival. These results are in accordance with the hypothesis that PPARA basal activity may protect liver cancer cells from death. Recent experiments on HepG2 cells support the hypothesis that PPARG activation may be related to cell proliferation while activation of PPARA leads to apoptosis [44]. In liver PPARA appears to regulate cell cycle progression and cell survival through P38MAPK pathway [45] [45]. This nuclear receptor has also be found to stimulate hepatic carcinogenesis in mice liver [46]. Taken together, these data point out a key role of PPARA in HCC.

Interestingly, we found that transcription of CEBPA, another important hepatic transcription factor, was induced by the basal activity of PKC, Gi/G0, Mek1/2 and P42/44. In humans CEBPA is highly expressed in liver [47] where it regulates hepatic cell differentiation by strong arrest of cell proliferation [48, 49]. CEBPA gene expression is deregulated in HCC [6] and recently, epigenetic mechanisms have been proposed to explain how CEBPA could be deregulated in HepG2 cells $[50,51]$. Our computational analyses also support the hypothesis of deregulation in methylation status in HCC genes (Figure 3B). We also found that CEBPA gene expression was induced by PPARA in HepG2 cells. Thus altered expression of CEBPA in many HCC might be the consequence of deregulations in the process of chromatine methylation, in activity or in transcriptional regulation of transcription factors, such as MYC [52] or PPARs [40]. Therefore a finely tuned regulation of CEBPA may represent a key event involved in the process of hepatic tumorigenesis.

In conclusion, combinatorial analyses of the global gene transcription networks, real time proliferation assay analysis of selected signaling pathways and gene expression analyses converged to identify key signaling pathways deregulated in human HCC. First we identified pathways related to cell survival (P42/44, PKC, Mek1/2, PPARA) and pathways involved in cell growth and proliferation (Gi/G0, JAK1, JNK and NFKB) in HCC cell lines. Second these pathways commonly control the expression of key transcription factors (i.e. they inhibit several tumor suppressors and they activate liver cell differentiation factor CEBPA). Most of the results are in agreement with published data, and this approach gives the opportunity to depict in few and rapid experiments an overall view of the molecular mechanisms involved in cell growth and proliferation. 


\section{ACKNOWLEDGEMENTS}

We would like to thank Emilie Viey (Roche Applied Science team from Roche

Diagnosis) for her kind technical support and Sophie Rome for revisiting the English text.

The authors declare that they have no conflict of interest with the present work. 


\section{REFERENCES}

[1] Tanaka, S., Arii, S., Molecular targeted therapy for hepatocellular carcinoma in the current and potential next strategies. J Gastroenterol 2010, 46, 289-296.

[2] Patil, M. A., Gutgemann, I., Zhang, J., Ho, C., et al., Array-based comparative genomic hybridization reveals recurrent chromosomal aberrations and Jab1 as a potential target for 8q gain in hepatocellular carcinoma. Carcinogenesis 2005, 26, 2050-2057.

[3] Aburatani, S., Sun, F., Saito, S., Honda, M., et al., Gene systems network inferred from expression profiles in hepatocellular carcinogenesis by graphical Gaussian model. EURASIP J Bioinform Syst Biol 2007, 47214.

[4] Teufel, A., Staib, F., Kanzler, S., Weinmann, A., et al., Genetics of hepatocellular carcinoma. World J Gastroenterol 2007, 13, 2271-2282.

[5] Hoshida, Y., Toffanin, S., Lachenmayer, A., Villanueva, A., et al., Molecular classification and novel targets in hepatocellular carcinoma: recent advancements. Semin Liver Dis 2010, 30, 35-51.

[6] Whittaker, S., Marais, R., Zhu, A. X., The role of signaling pathways in the development and treatment of hepatocellular carcinoma. Oncogene, 29, 4989-5005.

[8] Ito, Y., Sasaki, Y., Horimoto, M., Wada, S., et al., Activation of mitogen-activated protein kinases/extracellular signal-regulated kinases in human hepatocellular carcinoma. Hepatology 1998, 27, 951-958.

[9] Zender, L., Villanueva, A., Tovar, V., Sia, D., et al., Cancer gene discovery in hepatocellular carcinoma. J 7epatol 2010, 52, 921-929.

[9] Schmidt, C. M., McKillop, I. H., Cahill, P. A., Sitzmann, J. V., The role of cAMP-MAPK signalling in the regulation of human hepatocellular carcinoma growth in vitro. Eur J Gastroenterol Hepatol 1999, 11, 1393-1399.

[10] lyoda, K., Sasaki, Y., Horimoto, M., Toyama, T., et al., Involvement of the p38 mitogen-activated protein kinase cascade in hepatocellular carcinoma. Cancer 2003, 97, 3017-3026.

[11] Adachi, M., Brenner, D. A., High molecular weight adiponectin inhibits proliferation of hepatic stellate cells via activation of adenosine monophosphate-activated protein kinase. Hepatology 2008, 47, 677-685.

[12] Ng, S. K., Neo, S. Y., Yap, Y. W., Karuturi, R. K., et al., Ablation of phosphoinositide-3-kinase class II alpha suppresses hepatoma cell proliferation. Biochem Biophys Res Commun 2009, 387, 310-315.

[13] Calvisi, D. F., Ladu, S., Pinna, F., Frau, M., et al., SKP2 and CKS1 promote degradation of cell cycle regulators and are associated with hepatocellular carcinoma prognosis. Gastroenterology 2009, 137, $1816-1826$ e1811-1810.

[14] Xu, L., Hui, L., Wang, S., Gong, J., et al., Expression profiling suggested a regulatory role of liver-enriched transcription factors in human hepatocellular carcinoma. Cancer Res 2001, 61, 3176-3181.

[15] Tomizawa, M., Horie, H., Yamamoto, H., Matsunaga, T., et al., Reciprocal expression of CCAAT/enhancer binding proteins alpha and beta in hepatoblastomas and its prognostic significance. Oncol Rep 2007, 17, 341344.

[16] Berger, E., Rome, S., Vega, N., Ciancia, C., Vidal, H., Transcriptome profiling in response to adiponectin in human cancer-derived cells. Physiol Genomics 2010, 42, 61-70.

[17] Chang, K. J., Lin, J. K., Lee, P. H., Hsieh, Y. S., et al., The altered activity of membrane-bound protein kinase $\mathrm{C}$ in human liver cancer. Cancer Lett 1996, 105, 211-215.

[18] Schmidt, C. M., McKillop, I. H., Cahill, P. A., Sitzmann, J. V., Alterations in guanine nucleotide regulatory protein expression and activity in human hepatocellular carcinoma. Hepatology 1997b, 26, 1189-1194.

[19] Tsai, J. H., Hsieh, Y. S., Kuo, S. J., Chen, S. T., et al., Alteration in the expression of protein kinase C isoforms in human hepatocellular carcinoma. Cancer Lett 2000, 161, 171-175.

[20] Fuke, H., Shiraki, K., Sugimoto, K., Tanaka, J., et al., Jak inhibitor induces S phase cell-cycle arrest and augments TRAIL-induced apoptosis in human hepatocellular carcinoma cells. Biochem Biophys Res Commun 2007, 363, 738-744.

[21] Kusaba, M., Nakao, K., Goto, T., Nishimura, D., et al., Abrogation of constitutive STAT3 activity sensitizes human hepatoma cells to TRAIL-mediated apoptosis. J Hepatol 2007, 47, 546-555.

[22] Moon, D. O., Kim, M. O., Choi, Y. H., Hyun, J. W., et al., Butein induces G(2)/M phase arrest and apoptosis in human hepatoma cancer cells through ROS generation. Cancer Lett 2010, 288, 204-213.

[23] Sasse, J., Hemmann, U., Schwartz, C., Schniertshauer, U., et al., Mutational analysis of acute-phase response factor/Stat3 activation and dimerization. Mol Cell Biol 1997, 17, 4677-4686.

[24] Hah, N., Lee, S. T., An absolute role of the PKC-dependent NF-kappaB activation for induction of MMP-9 in hepatocellular carcinoma cells. Biochem Biophys Res Commun 2003, 305, 428-433.

[25] Chiao, P. J., Na, R., Niu, J., Sclabas, G. M., et al., Role of Rel/NF-kappaB transcription factors in apoptosis of human hepatocellular carcinoma cells. Cancer 2002, 95, 1696-1705.

[26] Alisi, A., Piemonte, F., Pastore, A., Panera, N., et al., Glutathionylation of p65NF-kappaB correlates with proliferating/apoptotic hepatoma cells exposed to pro- and anti-oxidants. Int J Mol Med 2009, 24, 319-326.

[27] Wu, L. F., Li, G. P., Su, J. D., Pu, Z. J., et al., Involvement of NF-kappaB activation in the apoptosis induced by extracellular adenosine in human hepatocellular carcinoma HepG2 cells. Biochem Cell Biol 2010, 88, 705-714. [28] Feo, F., Frau, M., Tomasi, M. L., Brozzetti, S., Pascale, R. M., Genetic and epigenetic control of molecular alterations in hepatocellular carcinoma. Exp Biol Med (Maywood) 2009, 234, 726-736.

[29] Pilarsky, C., Wenzig, M., Specht, T., Saeger, H. D., Grutzmann, R., Identification and validation of commonly overexpressed genes in solid tumors by comparison of microarray data. Neoplasia 2004, 6, 744-750.

[30] Sun, H. C., Li, M., Lu, J. L., Yan, D. W., et al., Overexpression of Forkhead box M1 protein associates with aggressive tumor features and poor prognosis of hepatocellular carcinoma. Oncol Rep 2011, 25, 1533-1539. 
[31] Yuen, M. F., Wu, P. C., Lai, V. C., Lau, J. Y., Lai, C. L., Expression of c-Myc, c-Fos, and c-jun in hepatocellular carcinoma. Cancer 2001, 91, 106-112.

[32] Hao, M. W., Liang, Y. R., Liu, Y. F., Liu, L., et al., Transcription factor EGR-1 inhibits growth of hepatocellular carcinoma and esophageal carcinoma cell lines. World J Gastroenterol 2002, 8, 203-207.

[33] Burns, K. A., Vanden Heuvel, J. P., Modulation of PPAR activity via phosphorylation. Biochim Biophys Acta 2007, 1771, 952-960.

[34] Okano, H., Shiraki, K., Inoue, H., Yamanaka, T., et al., Peroxisome proliferator-activated receptor gamma augments tumor necrosis factor family-induced apoptosis in hepatocellular carcinoma. Anticancer Drugs 2002, 13, 59-65.

[35] Toyoda, M., Takagi, H., Horiguchi, N., Kakizaki, S., et al., A ligand for peroxisome proliferator activated receptor gamma inhibits cell growth and induces apoptosis in human liver cancer cells. Gut 2002, 50, 563-567.

[36] Li, M. Y., Deng, H., Zhao, J. M., Dai, D., Tan, X. Y., PPARgamma pathway activation results in apoptosis and COX-2 inhibition in HepG2 cells. World J Gastroenterol 2003, 9, 1220-1226.

[37] Zhou, Y. M., Wen, Y. H., Kang, X. Y., Qian, H. H., et al., Troglitazone, a peroxisome proliferator-activated receptor gamma ligand, induces growth inhibition and apoptosis of HepG2 human liver cancer cells. World $\mathrm{J}$ Gastroenterol 2008, 14, 2168-2173.

[38] Koga, H., Harada, M., Ohtsubo, M., Shishido, S., et al., Troglitazone induces p27Kip1-associated cell-cycle arrest through down-regulating Skp2 in human hepatoma cells. Hepatology 2003, 37, 1086-1096.

[39] Yu, J., Qiao, L., Zimmermann, L., Ebert, M. P., et al., Troglitazone inhibits tumor growth in hepatocellular carcinoma in vitro and in vivo. Hepatology 2006, 43, 134-143.

[40] Tachibana, K., [Application of the human hepatoblastoma cell lines inducibly expressing peroxisome proliferator-activated receptors (PPARs)]. Yakugaku Zasshi 2007, 127, 1223-1229.

[41] Watkins, P. A., Ferrell, E. V., Jr., Pedersen, J. I., Hoefler, G., Peroxisomal fatty acid beta-oxidation in HepG2 cells. Arch Biochem Biophys 1991, 289, 329-336.

[42] Gulick, T., Cresci, S., Caira, T., Moore, D. D., Kelly, D. P., The peroxisome proliferator-activated receptor regulates mitochondrial fatty acid oxidative enzyme gene expression. Proc Natl Acad Sci U S A 1994, 91, 1101211016.

[43] Lee, W. N., Lim, S., Bassilian, S., Bergner, E. A., Edmond, J., Fatty acid cycling in human hepatoma cells and the effects of troglitazone. J Biol Chem 1998, 273, 20929-20934.

[44] Maggiora, M., Oraldi, M., Muzio, G., Canuto, R. A., Involvement of PPARalpha and PPARgamma in apoptosis and proliferation of human hepatocarcinoma HepG2 cells. Cell Biochem Funct 2011, 28, 571-577. [45] Cosulich, S., James, N., Roberts, R., Role of MAP kinase signalling pathways in the mode of action of peroxisome proliferators. Carcinogenesis 2000, 21, 579-584.

[46] Glauert, H. P., Calfee-Mason, K., Li, Y., Nilakantan, V., et al., The Role of NF-kappaB in PPARalphaMediated Hepatocarcinogenesis. PPAR Res 2008, 2008, 286249.

[47] Shyamsundar, R., Kim, Y. H., Higgins, J. P., Montgomery, K., et al., A DNA microarray survey of gene expression in normal human tissues. Genome Biol 2005, 6, R22.

[48] Diehl, A. M., Johns, D. C., Yang, S., Lin, H., et al., Adenovirus-mediated transfer of CCAAT/enhancer-binding protein-alpha identifies a dominant antiproliferative role for this isoform in hepatocytes. J Biol Chem 1996, 271, 7343-7350.

[49] Harris, T. E., Albrecht, J. H., Nakanishi, M., Darlington, G. J., CCAAT/enhancer-binding protein-alpha cooperates with p21 to inhibit cyclin-dependent kinase-2 activity and induces growth arrest independent of DNA binding. J Biol Chem 2001, 276, 29200-29209.

[50] Lu, G. D., Leung, C. H., Yan, B., Tan, C. M., et al., C/EBPalpha is up-regulated in a subset of hepatocellular carcinomas and plays a role in cell growth and proliferation. Gastroenterology 2010, 139, 632-643, 643 e631-634. [51] Dannenberg, L. O., Edenberg, H. J., Epigenetics of gene expression in human hepatoma cells: expression profiling the response to inhibition of DNA methylation and histone deacetylation. BMC Genomics 2006, 7, 181. [52] Li, T., Wan, B., Huang, J., Zhang, X., Comparison of gene expression in hepatocellular carcinoma, liver development, and liver regeneration. Mol Genet Genomics 2010, 283, 485-492. 


\section{LEGENDS OF FIGURES}

Table 1: mRNA levels of target genes modulated by peroxisome-proliferator activated receptors alpha activator GW7647 $(1 \mu \mathrm{M})$ in HepG2 cells (cultured for 5 hours without serum). Fold changes (stimulated versus control) were normalized to HPRT1, significantly modulated genes identified by ANOVA test $(p<0.001)$. For complete gene names and sequence references, see Supporting information, Table S4.

\section{Genes activated by GW7647:}
EGR1
$8.45 \pm 0.12$
PPARGC1A
$3.76 \pm 0.60$
HES 1
$1.81 \pm 0.02$
ADIPOR1
$1.79 \pm 0.04$
FOXM1/HNF3 $1.75 \pm 0.04$
$\operatorname{AFP} \quad 1.73 \pm 0.41$
CREBBP
$1.65 \pm 0.05$

\section{Genes repressed by GW7647:}

CEBPA $\quad 0.42 \pm 0.01$

\section{Genes not modulated by GW7647:}

ADIPOR1, BHLHB2, CEBPB, FABP1, FOXO1A, LDLR, MYC, PPARG, TBP 
Figure 1: The 31525 of human genes contained in the Fatigo+ database were separated into subsets. Set 1 contained the hepatic genes detected in HepG2 cells; set 2 the hepatic genes deregulated in hepatocellular carcinoma and present in HepG2 cells. Then we determined, among these 2 subsets of genes, the percentage of genes affected by different external stimuli, or modulated by known intracellular pathways and transcription factors by using previously published data which are reported in the Supporting information, Tables S1 and S2.

Figure 2 : Functional enrichment analysis of the biological functions by using Fatigo+ software in (A) Hepatic genes expressed in HepG2 (gene set 1) and deregulated in hepatocellular carcinoma (HCC, gene set 2) compared to all human genes (31 524 genes). Only most representative biological functions. i.e. highest hierarchical clustering Level 6, are presented and were found to be significantly over-represented in both gene sets (Fisher's exact test, adjusted p-value <0.001). (B) Biological functions significantly over-represented in the list of HCC genes (gene set 2) in comparison to hepatic genes (gene set 1) (highest hierarchical clustering Levels 3-5). X-axis represents the number of genes involved in these functions in either healthy liver and in HCC. Genes selected for further analyses are indicated on the right side of the panel. For complete gene names, see Supporting information, Table S4.

Figure 3 : Identification of signaling pathways specifically over-represented in human healthy liver and in hepatocellular carcinoma (HCC) from analysis of previously published transcriptional data. Frequency of genes regulated (x-axis) by either (A) external signals (Stimulus, 21 data sets) and (B) intracellular signaling pathways (20 data sets) were calculated with sets of genes detected in HepG2 cells (Full set), specific to healthy liver and deregulated HCC. Significant differences (i.e. Z-test scores with confidence level > 90) indicated by asterisks represent pathways over-represented in either liver and HCC sets potentially linked to hepatic functions, significant differences in HCC versus liver (barrels and asterisks) identify pathways which may be affected in HCC. Target genes selected for validation by qRT PCR analysis are shown in italics. For complete gene names and references, see Supporting information, Table S4. Sets of human genes retrieved from published global gene analyses (According to the procedure previously described [16]). Complete data and references are provided in Supporting information, Table S2. 
Figure 4: Identification of transcription factors potentially involved the regulation of healthy liver gene transcription and deregulated in hepatocellular carcinoma (HCC). (A) Bioinformatic analysis through statistical Fatigo+ screening of binding site enrichment : frequency of given binding site in either liver (hepatic genes detected in HepG2 cells, gene set 1, 4918 genes) and HCC (gene set 2, 806 genes) was compared to the complete set of genes detected in HepG2 cells (20 942 genes). Only binding sites with significant differences in representativity in either healthy liver and HCC are shown $(p<0.05)$. (B) According to the procedure previously described [16], sets of human genes modulated by transcription factors were retrieved from published experiments (53 sets). For each transcription factor, frequency of genes (x-axis) modulated was calculated for either genome, liver and HCC gene sets. Z-test calculation was applied on adjusted gene sets (restricted to sets of genes modulated by at least one transcription factor) to compare these frequencies in either liver (4918 genes) and HCC (505 genes) versus rest of genome (4736 genes) (represented by an asterisk), or HCC versus liver profiles (barrel with asterisk). Only transcription factors sets with significant differences in representativity are shown, i.e. 34 sets (confidence level $>90$ ). Full data sets and references are provided in [16]. Genes selected for validation by qRT PCR are indicated in italics (for gene names and references, see Supporting information, Table S4).

Figure 5: Analysis of signaling pathways involved in HepG2 cell survival and/or proliferation by real time monitoring of cell number on xCELLigence system. HepG2 cells were seeded at 5000 cells/E-plate well and grown in FCS containing medium for $24 \mathrm{~h}$. Then medium was replaced by FCS-deprived medium containing either vehicle or specific inhibitors at several concentrations. Left panels represent cell indexes calculated at time $x(t x)$ normalized at the time of the inhibitor was applied (t0), i.e. cell index at $t x$ divided by cell index at $t 0$. The cell index was measured every $5 \mathrm{~min}$ in 50 cycles, followed by every $15 \mathrm{~min}$ for $48 \mathrm{~h}$ (x-axis). Right panels report corresponding curve slopes calculated at indicated times, depanding on inhibitor activity: (A) highly sensitive intracellular pathways (slopes calculated for cell indexes measured during 1 hour after treatment); (B) slight sensitive intracellular pathways (slopes calculated for cell indexes measured during 24 hours). (C) Selective activation and/or inhibition of transcription factors (slopes calculated for cell indexes measured during 24 hours).

Data are presented as mean values \pm SEM (representative experiments with at least 5 replicates). Significant differences were determined through Student's test, i.e. p-values $\left.\left.p<0.05\left(^{*}\right), p<0.001{ }^{* *}\right), p<0.0001^{(* *}\right)$. For inhibitor complete nomenclature see Supporting information, Table S3. Abbreviations: JNK: Jun-NH2 kinase; JAK1: janus kinase 1; NFKBp65: nuclear factor kappa B, p65 subunit; PKC : protein kinase C; PPARA: peroxisome-proliferator activated receptor alpha. 
Figure 6 : Transcriptional networks regulated by signaling pathways involved in HepG2 cell growth and/or survival. The central panel represents the set of genes analyzed by qRT PCR. The grey stone genes were not modulated by any drug tested. In the left panel are reported the signaling pathways involved in cell growth and/or survival and in bold black lines their target genes (panel A). Genes regulated by at least 3 pathways (white fonts) were selected for further analysis. In the right side (grey lines) are linked the transcription factors regulating these genes as reported in previously published microarray data sets [16] (panel B). Black lines represent links validated by $\mathrm{qRT} P C R$ in HepG2 cells using specific activator of peroxisome-proliferator activating receptor alpha (PPARA). Transcription factors modulated by P42/44 in human cells are indicated by asterisks. Full qRT PCR data are included in Supporting information, Table S5 and Table 1. 